\title{
Participación electoral femenina en la victoria del Frente Popular y su contribución a la protesta social en la primavera del 36
}

\author{
Paloma Seoane Amigo \\ Doctora en Historia Contemporánea por la Univ. Complutense de Madrid
}

\begin{abstract}
The participation of left wing and republic women in the victory of the Frente Popular and their involvement in social unrest during the spring of 1936
\end{abstract}

\begin{abstract}
Resumen
Se pretende con el presente estudio poner el acento en lo denunciado, tantas veces,

en la historiografía de género como

«invisibilidad femenina», con el objetivo

último de comprender la problemática

socio-política a la que se ha visto

subyugada la mujer durante el lapso de

tiempo que transcurre desde el triunfo del

Frente Popular hasta los comienzos de la

Guerra Civil. Todo ello con la intención de

contribuir intelectualmente al esfuerzo

iniciado por otras colegas historiadoras en

la materia, enfatizando en aquellos

aspectos menos conocidos, o en aquellos otros que han pasado más desapercibidos en determinados círculos académicos. $\mathrm{La}$

mujer participa activamente en la vida política republicana, su voto es decisivo en la victoria del Frente Popular; asi

mismo, es destacable su creciente influencia en el entorno sindical, siendo víctima por este motivo de la represión franquista posterior. Durante el estudio destacamos la activa participación de la mujer republicana y de izquierdas en la campaña electoral de 1936, y su intervención en la conflictividad sociolaboral durante la primavera de 1936. La
\end{abstract}

Abstract

The paper emphasizes the «female historical invisibility", many times reported in Gender Historiography, with the ultimate goal of understanding the socio-politic causes that have subjugated women during the period elapsed since the victory of the Frente Popular to the begining of the Spanish Civil War. This paper is, also, to add a small contribution to the significant effort developed by some colleagues on this field of study, and it stresses somo aspects less known and less studied. During the reporting period, women play an important role in trade unions, wich be the causes for the later repression, already in the begining on Franco Period. This study highlights the active participation of left wing an republican women in the election campaing of 1936, and their involvement in social unrest during the spring of 1936. Supporting Frente Popular, Women will play an important role in the capaign, and many of them will made, also, their own "campaign" with specific acts such as travelling around the country, promoting and leading numerous campaign events or developing acts in favour of amnesty. 
mujer juega un papel relevante en la campaña electoral, apoyando las listas del Frente Popular. Muchas mujeres hicieron su propia "campaña» particular, con actos de apoyo al Frente Popular y en pro de la amnistía; recorriendo todo el país, impulsando y encabezando numerosos actos electorales. Basaron

fundamentalmente sus acciones en cuestiones de naturaleza económica y en todo aquello relacionado con la lucha política clásica.

Palabras clave:

Mujeres , España, Frente Poupar, elecciones, protesta social, primavera de 1936.
Women topics on campaign were about economics and classical political struggle.

Key Words

Women, Spain, Frente Popular, election, social unrest, Spring of 1936

\section{DISCURSOS Y POSTURAS DE LA IZQUIERDA ANTE EL VOTO FEMENINO}

En este trabajo presento algunos de los desarrollos que realicé con más extensión en mi Tesis Doctoral ${ }^{1}$. El triunfo del Frente Popular $^{2}$ en las elecciones del año 36 fue presentado desde la izquierda como un antídoto frente al ascenso del fascismo. La extrema izquierda opondrá un argumento pasional y sensible: «Silencia a los verdugos de octubre». El alcance y la magnitud de la represión que siguió a la «Revolución de Octubre» del 34 favorecerá la unión coyuntural entre los partidos de izquierda y convocará a los defensores de la opción democrática ante un hecho contundente y doloroso: los más de treinta mil presos políticos y sociales que permanecían en las cárceles por su participación en la huelga de 1934.

Un editorial de El Socialista calificaba el acuerdo para acudir a las urnas como «un pacto de transigencia común». El Socialista, al dar cuenta del acto del 28 de enero de 1936 que inauguraba la campaña electoral de la coalición de los partidos de izquierda, opinaba que el resultado iba a ser fructífero.

En las elecciones del 36, la coalición de izquierdas pondrá el acento en la necesidad de atraerse al electorado anarquista y femenino con el objeto de lograr la victoria. Las aspiraciones a una igualdad plena entre los sexos fueron identificadas con el momento del triunfo de la República. La unión de las izquierdas podría asegurar la derrota del fascismo y el triunfo de los ideales igualitaristas. Ideológicamente, el discurso de las izquierdas estaba cargado de una visión positiva de progreso y de un deseo de modernización frente a la pervivencia o regeneración de

1 Modernización política y laboral, democracia social y movilización femenina en España (19001939). Madrid, Universidad Complutense de Madrid, Servicio de Publicaciones, 2010. ISBN: 978-84-6929942-5. 
lo tradicional, incidiendo en el riesgo que suponía dejar que prosperara la idea de mujer que mantenía la derecha y que implicaba la vuelta, en el propio decir de sus portavoces, a un modelo medievalizante («producto de una civilización decadente»).

El modelo izquierdista de mujer, por su parte, venía asociado al tipo de sociedad que se quiere construir de cara al futuro: democracia frente a fascismo, revolución frente a tradición. En 1936 la celebración de elecciones legislativas dio una importancia estratégica a la captación de la mujer a partir de una valoración teórica sobre las ventajas políticas de una captación masiva del voto femenino, más que como producto de una reflexión de las múltiples facetas que la problemática de la mujer plantea. Las mujeres pasaban a ser, por tanto, una presa política disputada.

La maternidad pasó a ser desplazada del campo de lo biológico al campo de lo social. La defensa de la «maternidad social» (como fuente de derechos y de ciudadanía femenina) se justificó en la prolongación a la esfera pública de los papeles de madre y esposa. Desde que en octubre de 1931 se les otorgara el sufragio, todos los partidos y sindicatos se esforzarán por captar a las mujeres para su causa ${ }^{3}$, incorporando en sus programas reivindicaciones femeninas, aunque sin romper los moldes convencionales de representación de la mujer ${ }^{4}$.

El discurso empleado, de este modo, no la hizo a ella receptora del mensaje, sino que iba destinado a terceros: sus hijos, su compañero en el trabajo, su pareja. Son abundantes la referencias a sus tradicionales funciones como madre y esposa, realizando en función de "otros» (hijos, compañero o familia), y no de sí mismas, sus actividades, actividades en el centro de las cuales se sitúa la maternidad, en la mayoría de los periódicos y revistas. En virtud de su autoridad moral en calidad de madres ( $y$ en razón de las virtudes éticas que la mujer podría inyectar en la política), se le otorgó el papel de socializadora de sus hijos, asignándole como tarea primordial la responsabilidad de su educación y formación cívica.

El discurso de la domesticidad, que exaltaba la maternidad como tarea principal de las mujeres, pasó a ocupar un lugar central también en el discurso político socialista de la época ${ }^{5}$ que iba dirigido a la mujer o venía referido a ella. El igualitarismo originario cedió su lugar al discurso maternal, que exaltaba la polaridad de las identidades masculinas y femeninas y marcaba la diferenciación entre la ciu-

2 Sobre el proceso de formación del Frente Popular y las diferentes concepciones existentes sobre éste en las distintas organizaciones, JULIÁ S., Orígenes del Frente Popular en España (1934-1936), Madrid, Siglo XXI, 1979.

3 CAPEL, R. M. a , El sufragio femenino en la Segunda República, Granada, Universidad de Granada, 1975; DOMINGO, C., Con Voz y voto: las mujeres y la política en España (1931-1945), Barcelona, Icaria, 2004.

4 CAPEL, R. M. ${ }^{\text {a }}$ «Mujer y política en la Segunda República», Revista del Instituto de Ciencias Sociales, núm. 29 (1977), p. 197.

5 LARGO CABALLERO, F., Discursos en la campaña de las elecciones de febrero de 1936 que dieron el triunfo al Frente Popular, Rosario, Juventud Socialista Deportiva y Cultural, 1936. 
dadanía política de hombres y de mujeres. En 1936 los socialistas utilizaron de nuevo el mismo lenguaje y la misma concepción diferenciadora que antes señalamos, referidos a la mujer. Así, ésta seguiría constituyendo no un ente con personalidad autónoma, sino un factor caracterizado primordialmente por sus relaciones con el marido y con sus hijos. Su discurso en torno a la mujer era por tanto poco innovador, y se articuló a partir de la ideología de la separación de las dos esferas y del papel social que la mujer tenía como madre y responsable de la familia. En los comicios de 1936 los socialistas apelarán además a la sensibilidad maternal y al compromiso político de las mujeres (madres, esposas), solicitando su voto con el objetivo primordial de excarcelar a los presos políticos de 1934.

Por su parte, el lenguaje y los objetivos comunistas con respecto a la mujer habían cambiado conforme a la nueva orientación frentepopulista adoptada por la III Internacional Comunista en su VII Congreso Internacional, que, como es sabido, se había celebrado en Moscú del 25 de julio al 17 de agosto de 1935, en una orientación destinada a hacer frente a los problemas políticos europeos. A partir de este momento, el PCE preconizará la formación de un Frente Único y con él, de un Gobierno de Frente Popular, y pedirá el apoyo y el voto de la mujer por dos motivos fundamentales: para lograr el más rápido aplastamiento del fascismo, y para lograr la amnistía de los más de treinta mil presos políticos y sociales existentes en las cárceles ${ }^{6}$. También desempeñó un papel importante en la propaganda electoral la noción de unidad, como única solución posible para derrocar la República burguesa y para conseguir la implantación de un régimen socialista. En caso de lograrlo, se pensaba lograr liberar a la mujer del doble yugo opresor masculino y de la «agresión reaccionaria».

Porque la situación de inferioridad de la mujer en la sociedad capitalista, se dice una vez más, se debe a su explotación como asalariada. El análisis a propósito de la subordinación social de la mujer se reduce de ese modo al problema general de la lucha de clases y a su posible aportación a ésta ${ }^{8}$. El camino hacia la emancipación de las mujeres se trazará a partir de su inserción en la lucha de clases, con su incorporación en la lucha propuesta por el PCE. La dirigente comunista Dolores Ibárruri insistía en ello: « ¡Mujeres! ¡Trabajadoras!. Ocupad vuestro puesto en la lucha al lado del Partido Comunista, al lado de los que luchan por la tierra para quienes la trabajan, por el pan para todos los trabajadores, por la paz y el bie-

\footnotetext{
6 Ha sido fundamental para este trabajo la consulta de prensa y de carpetas de recortes y octavillas que se guardan en el Archivo del PCE. Véase RAMOS, V., Catálogo de los fondos del Archivo Histórico del Partido Comunista de España, Madrid, Fundación de Investigaciones Marxistas, 1997. HEINEN, J., De la I a la III Internacional: la cuestión de la mujer, Barcelona, Fontamara, 1978. «iTrabajadores, antifascistas, mujeres!». Octavilla del Radio Sur de Madrid del PCE y UJCE. Madrid, febrero de 1936. AHPCE. Film XIV (153); «iTrabajadores, mujeres!». Octavilla del Radio Norte de Madrid del PCE ante las elecciones de febrero. AHPCE. Film XIV (189); «¡A todas las mujeres españolas!». Manifiesto electoral del SRI. AHPCE. Film XIV (189).

7 NASH, M., Mujer y movimiento obrero en España. 1936-1939, Barcelona, Fontamara, 1981.

8 IBÁRRURI, D., «¡Mujeres!. ¡Madres de España, de Euskadi, de Galiciaj», Mundo Obrero, 8/2/1936, p. 6 .
} 
nestar del pueblo laborioso... iMujeres! Votad al Bloque Popular, por lo que significa de progreso, de libertad, de justicia... ¡Mujeres! ¡Madres! ¡Hermanas! Por vuestra dignidad; por el derecho de la mujer al trabajo y a la igualdad de salarios; ... por la defensa de todos nuestros derechos y de todas nuestras reivindicaciones, todas en pie al lado del Bloque Popular»?.

El discurso comunista pide así el voto de la mujer para la coalición de izquierdas porque sólo el triunfo del Frente Popular supondría su progreso, libertad y justicia frente al ideal de regeneración y conservación que le ofrecen en cambio los partidos conservadores, como se ha puesto de relieve también en la historio-

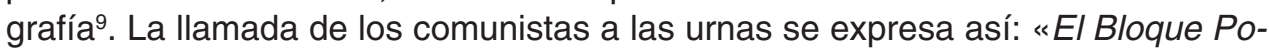
pular reclama vuestro apoyo, vuestra adhesión incondicional, vuestros votos. El Bloque Popular os ofrece trabajo para vuestros maridos y para vuestros hijos. Se compromete a velar por el porvenir de éstos. Os asegurará jornales justos. jA igual trabajo igual salario!... Defenderá vuestros derechos democráticos.... Luchará por vuestra emancipación, por vuestra incorporación definitiva a la vida del trabajo.... ¡Mujeres del pueblo, obreras, empleadas: votad al Bloque Popular!» ${ }^{10}$.

Las centrales anarquistas CNT-FAI decidieron hacer campaña a favor de la abstención, pero no así algunos dirigentes que, teniendo en cuenta las circunstancias especiales, decidieron en aquella ocasión no dar la consigna de no votar. Así lo expresaba, el 5 de febrero de 1936, el líder sindical Buenaventura Durruti en unas declaraciones suyas a la prensa escrita: «No puedo recomendar a nadie que no vote. Solamente he de decir que los obreros obren con arreglo a su conciencia» ${ }^{11}$. La abstención en las urnas, se advertía sin embargo, favorecería el triunfo de las candidaturas conservadoras. Francisco Ascaso, en cambio, explicó a los asistentes que podían, si así lo deseaban, votar (como «una diversión»), pero que era «indudable que no conseguiremos nuestras aspiraciones mientras no hagamos la revolución ${ }^{12}$. En este sentido, se había dado un gran paso desde el I Congreso extraordinario de la CNT celebrado en Madrid en 1919, donde se había aceptado el eslogan Solos contra todos . Solidaridad Obrera, con el prestigio adquirido entre los militantes, prosigue mientras tanto en sus editoriales su esperada campaña abstencionista.

Pero las militantes anarquistas no siempre se contentan con la aceptación acrítica de las ideas de la acracia o con los giros tácticos que pudieran adoptarse. La dirigente anarquista Lucia Sánchez Saornil criticó aquel interés del movimiento libertario por captar a la mujer hacia la causa libertaria sin plantearse ningún género de cambios en su propia concepción acerca de la dominación del hombre sobre

9 «Otro gran objetivo de los panfletos cedistas es la mujer. Se identifica a las mujeres con la familia y el hogar e incluso el amor, y se hace una alusión especial a la religiosidad de la mujer española». TUSELL, J., Las elecciones del Frente Popular, I, Madrid, Edicusa, 1971, p. 215.

10 «Mujeres del pueblo», Mundo Obrero, 30/1/1936, p. 4.

11 El Socialista, 4/2/1936, p. 6.

12 La Libertad, 22/1/1936. 
la mujer ${ }^{13}$. El empleo interesado de la mujer (en razón del valor de su voto) tampoco estaría ausente, en los círculos anarquistas, de un análisis afinado de la condición político-social general de la mujer española.

Los anarquistas insisten así especialmente, como otros sectores de la izquierda laica, en la importancia de la Iglesia católica en España como vehículo de transmisión de la ideología conservadora entre las mujeres, y consideran que la mujer está todavía bajo el dominio social e ideológico de la religión, encarnada en el párroco o el confesor. Justo antes de las elecciones de 1936, el periódico anarquista Tierra y Libertad sostiene que la mujer votante española era por esto una "calamidad», y que la Segunda República "acabó de hundirse» en octubre de 1931 con la concesión del sufragio femenino ${ }^{14}$.

Pero los anarquistas apenas crearon tampoco, por su parte, centros de capacitación profesional y cultural para la mujer que sirviesen a su vez como instrumento de inserción de las mujeres en los ideales libertarios. No era fácil, con todo, llevar a cabo con éxito una tarea de este tipo. María Luisa Cobos y Trinidad Urien, por ejemplo, se ven obligadas a rechazar la idea de militantes como Montuenga ${ }^{15}$ o Daniel Berbegal, que atribuyen la presencia de la mujer en los medios anarquistas a una motivación exclusivamente «social» (y es que las «malas lenguas» consideraban los círculos libertarios como lugares de relaciones promiscuas), a la vez que, en el extremo opuesto, han de rebatir las posturas de ciertos anarquistas, en exceso optimistas, que consideraban que el hombre había superado ya en aquellos momentos los prejuicios sexistas históricos, hasta el punto de mantener unas relaciones de camaradería e igualdad con sus compañeras. Podrían ser incluso los mismos libertarios, por el contrario y más de una vez, quienes obstaculizasen el cambio revolucionario a favor de las mujeres en el seno de sus propias filas.

Y es que los anarquistas seguían menospreciando la importancia de la mujer en la lucha social, y no se molestaban por lo general en discutir sus ideas con sus compañeras, se sorprendían muchas veces de ver a sus propias mujeres en los mítines, y cuando éstas expresaban sus ideas en público, se preguntaban «¿Será una loca...? » ${ }^{16}$. Con todo su fondo alternativo, con toda su radicalidad, podría ser que no se distinguieran apenas del resto de los obreros en cuanto a este aspecto decisivo de la conciencia social y democrática.

Existen, sin embargo, intentos prácticos de integrar a la mujer en el movimiento libertario español, con programas de promoción cultural y social. En este sentido, Tierra y Libertad inauguraba en diciembre de 1935 una «Página de la mujer», y la Revista Blanca lanzó dos series de novelas propagandísticas, «La Novela

13 SÁNCHEZ, L., «La cuestión femenina en nuestros medios», Solidaridad Obrera, 15/10/1935.

14 Tierra y Libertad, 7/2/1936, p. 2.

15 MONTUENGA, «Consideraciones sobre la mujer», Solidaridad Obrera, 4/9/1935.

16 MORALES GUZMÁN, A., «Ocupémonos de la mujer», Tierra y Libertad, 12/7/1935, p. 3. 
Ideal» y la «Novela Libre», cuyas heroínas encontraban la dignidad y la felicidad en la independencia económica, el amor libre y la activa participación en la lucha social. Sus páginas, aunque dedicadas específicamente al sexo femenino, intentan impulsar un cambio de actitud en los hombres frente al sexo femenino y, a la vez, elevar la conciencia social de las mujeres. Desde ellas, se exhortaba al varón a que abandonara sus tradicionales ideas reaccionarias, incompatibles con el ideal anarquista.

\section{MUJERES, CAMPAÑA ELECTORAL Y ELECCIONES DE 1936}

La campaña electoral del año 36 fue muy violenta, no sólo por los frecuentes enfrentamientos callejeros sino también por los argumentos verbales que se emplearon ${ }^{18}$. En las elecciones del 36 se constata una evidente coincidencia entre los diversos sectores a la hora de considerar el proceso electoral como decisivo para el futuro del país, por lo cual el acto pre-electoral cobra el carácter de verdadero acto plebiscitario. Democracia, órgano de la Federación Provincial Socialista de Jaén, cifraba la asistencia a un acto celebrado el 16 de enero de 1936 en la Casa del Pueblo de Torredonjimeno, en Jaén, en «más de seis mil trabajadores y mujeres». Dirigen el grueso de su propaganda, a conquistar el proletariado femenino, sobretodo en las zonas más proletarizadas. Un grupo de sirvientas se dirige a las trabajadoras del servicio doméstico en los siguientes términos: "Trabajadoras del hogar: El día 16 de febrero vamos a concurrir ante las urnas para depositar nuestro voto... Por nuestra propia condición, hemos venido siendo elementos fáciles de la explotación... y son estos señoritos nuestros, los que ahora ante las elecciones quieren coaccionarnos a que votemos sus candidaturas... que representan la explotación y la tiranía... Nunca, ...Frente a esas candidaturas... está la candidatura del Frente Popular... El triunfo del Frente Popular es la seguridad que tenemos de alcanzar una mejor situación... Y nuestro deber ahora, es votar al Frente Popular de izquierdas ${ }^{19}$.

El volumen de la propaganda electoral muestra también un grado de politización que traslada un grado de conciencia ciudadana infinitamente superior al de etapas pretéritas, lo que supone también que la política electoral tiende a ser en ocasiones maximalista, con proclamas exaltadas sobre la inminencia de un nuevo orden «revolucionario». La escisión del Partido Radical trajo una fuerte polarización a estos comicios. El secretario de Azaña, Santos Martínez Saura, cifraba en sus memorias los actos de la coalición electoral derechista: ya sólo el domingo anterior a las elecciones, eran según él 387, en tanto que los de los partidos centristas alcanzaban 300 y los organizados por el Frente Popular llegaban

\footnotetext{
17 «Hombres y mujeres de sentimientos libres y humanitarios. ¡Apoyad al Bloque Popular de izquierdas!», Mundo Obrero, 28/1/1936, p. 4.

18 Democracia, 17/1/1936.

19 Propaganda electoral, octavilla. AHPCE, Sección Documentos PCE, Film XV (189).
} 
a ser más de $361^{20}$. La propaganda electoral de los partidos izquierdistas había utilizado también, en dichos actos, el símbolo de la maternidad y la identificación de la identidad femenina con su función maternal, así como la exaltación de un futuro cargado de esperanza, para los hijos y para ellas mismas, como recursos electorales de primer orden para atraer a las mujeres a sus partidos: «La CEDA significa: Fanatismo, Dictadura y Privilegios. // El Frente Popular significa: Cultura, Justicia y Libertad. // ;Votad a las izquierdas! ${ }^{21}$.

Apelarán así a las mujeres en su condición de dadoras y conservadoras de la vida y de protectoras del bienestar familiar: «Mujer: ¿Qué te prometieron las derechas en las últimas elecciones y que te han dado estas promesas...? ?22. Encarnación Fuyola, la secretaria general de la Agrupación de Mujeres Antifascistas, se preguntaba el mismo día de las elecciones: «¿Por quién van a votar las que han visto descender este año, bajo el dominio triunfante del cacique, los salarios de recogida de la aceituna en Extremadura a una peseta con jornadas de sol a sol...? ¿Por quién van a votar las que han visto en Andalucía reducidos sus jornales a treinta céntimos diarios? ¿Por quién van a votar las mujeres que pasan el día en el monte recogiendo hierbas o bellotas..., único alimento que podrán dar a los hijos, porque el compañero hace seis, siete, nueve meses que no trabaja?»23. Victoria Gómez se preguntaba a su vez, el mismo día de los comicios: “¿Habrá alguna mujer que se sienta indiferente ante cosas que tanto afectan a nuestros sentimientos?», pidiendo su voto «por el porvenir de nuestros hijos, por la seguridad de nuestro presente, por nuestra condición de trabajadoras, votad a las izquierdas y contribuiremos a la obra de paz, de justicia y de trabajo que desean todas las madres y mujeres de España?»24.

Muchas mujeres, así contagiadas de la intensidad política del momento que se vivía, influenciadas por el amplio movimiento popular en torno a las candidaturas del Frente Popular y por las promesas de amnistía y de mejoras salariales y de mayores puestos de trabajo, hicieron su propia «campaña» particular, con actos de apoyo al Frente Popular y en pro de la amnistía, y batallaron por conseguir unas condiciones existenciales dignas. Ganar las elecciones y defender la República constituían el común denominador de sus aspiraciones. El triunfo del Frente Popular significaba encauzar el triunfo de sus aspiraciones, y por ello orientarán su acción hacia la consecución de este propósito. Sus objetivos primordiales consisten, de ese modo, en que las mujeres participen en los comicios, y utilizan para ello el señuelo electoral de la amnistía.

De ahí que la palabra amnistía desempeñe un papel destacado en todos los panfletos. La Comisión electoral femenina de Cuatro Caminos, en Madrid, se diri-

20 MARTínEZ, S., Memorias del secretario de Azaña, Barcelona, Planeta, 1999, p. 276.

21 Propaganda electoral, octavilla. AHPCE, Sección Documentos PCE, Film XV (189).

22 AHPCE, Sección Documentos PCE.

23 FUYOLA, E., «¿A quién votarán las mujeres campesinas?», Mundo Obrero, 11/2/1936, p. 1.

24 GÓMEZ, V., «jMujeres! ¡Compañeras!», Mundo Obrero, 16/2/1936, p. 4. 
ge a las mujeres en los siguientes términos: «Mujeres: De un lado las derechas con su demagogia, terror, salvajismo, penas de muertes, fascismo, guerras. Mujeres: De otro lado el B. P. A. con su programa de paz, libertad, cultura y progreso», pidiendo su voto « ¡Por un régimen de libertad! ¡Por la amnistía de nuestros 30.000 presos!... ;Contra la CEDA... ;Contra el fascismo que es la miseria de vuestros hogares!...;Contra el fascismo que es la Guerra! ${ }^{25}$. Se sigue el modelo de la Revolución Rusa de 1917. Julia Álvarez, candidata socialista, lo expresaba más contundentemente al afirmar sin paliativos que «El frente único es el preparador de una España soviética» ${ }^{26}$. Aunque como hemos dicho iba a invocarse la sensibilidad maternal para fomentar la adhesión de las indecisas y comprometerlas, a ellas también, a apoyar las candidaturas progresistas, el antifascismo y el antibelicismo, compartieron honores con la función de madre, en cuanto a su papel en el discurso hablado. La propia Julia Álvarez, desde las páginas del número 1 (15 de febrero de 1936) de la revista Mujeres, se dirigía de esta manera a las votantes potenciales: "Escucha mujer, ique cada voto vuestro sea un golpe en la reja de los presidios contra la guerra y el fascismo».

La dirigente comunista Dolores Ibárruri salió de la cárcel para hacer campaña electoral, presentándose en las listas electorales del Frente Popular como candidata a diputado por el PCE en la circunscripción electoral de Oviedo, y realizó un intenso trabajo de propaganda y organización. Ibárruri cuenta en sus memorias, por ejemplo, cómo «en los últimos días del año de 1935, el Partido Comunista me envió a Galicia a participar en actos de propaganda organizados por el Comité Provincial de La Coruña» ${ }^{27}$. El 15 de enero de 1936 Ibárruri fue detenida a su regreso de Asturias, por su defensa de los intereses del proletariado, bajo la acusación de «conceptos vertidos en actos de propaganda» 28 . Ibárruri había defendido anteponer la unidad en aras de la victoria. Evocó en sus discursos experiencias -la vida de opresión que arrastran-y sentimientos compartidos por todas las mujeres, y apeló a su solidaridad para combatir aquella común y generalizada subordinación.

Junto a ella hubo otras, como Lina Odena, que cumplió una gira electoral por Asturias con Dolores Ibárruri, en la que se exhortó a las mujeres y madres como se haría o se había hecho también con las de Madrid, de Cataluña, Euskadi y de Galicia, para que votasen las candidaturas del Frente Popular. Se pidió el voto y el apoyo de la mujer por dos objetivos primordiales: la amnistía de los procesados por delitos políticos y la liquidación de las consecuencias de la represión del movimiento revolucionario de Octubre. Ibárruri fundamentó la campaña electoral en el recordatorio a los trabajadores y trabajadoras de los desmanes y atropellos cometidos contra el proletariado asturiano, y en otras experiencias dolorosas vividas por el pueblo trabajador durante el bienio radical-cedista: despidos selectivos, en-

25 Circular, AHPCE, Sección Documentos PCE, Film XV (189)

26 «Del mitin de ayer en el Cinema Europa», Mundo Obrero, 6/1/1936, p. 4.

27 IBÁRRURI, D. El único camino, Madrid, Editorial Castalia, 1992, p. 313.

28 «Pasionaria' continúa en la cárcel», Mundo Obrero, 18/1/1936, p. 3. 
vilecimiento de salarios y violación de los derechos y libertades fundamentales. El Frente Popular contó con muy pocas candidaturas femeninas, sin embargo. Muy pocas mujeres encabezaron una lista electoral, lo cual restringió la posibilidad de que resultaran elegidas. Política destaca la expulsión del seno de la Juventud Radical Socialista de su presidenta (que optaba por Las Palmas), Josefina Perdomo Benítez, «por haber presentado su candidatura para las próximas elecciones con carácter progresista» 29 .

De otra parte, en un artículo del semanario Estampa, del 18 de enero de 1936, con motivo de la celebración de las elecciones, Miguel Lillo destacaba la decisión de Alicia Salcedo, primera abogada de Asturias, «de entrar de lleno en la lucha social», decisión que dice estar «orientada en un principio político: la causa común de las derechas» ${ }^{30}$. Que no hubiera apenas mujeres en las listas no significa que las mujeres no contribuyeran a la campaña, sin embargo. En los círculos socialistas de las barriadas del sur de Madrid, las militantes Marujita Rodríguez, Marujita Grijalva y Carmen y Adriana López, por ejemplo, participaron de forma activa en la comprobación del censo electoral y en diferentes tareas propagandísticas, como pegar pasquines. ${ }^{31}$

Las Juventudes Comunistas colaboraron activamente con las Comisiones electorales del Frente Popular en la recogida de donativos y a hacer tarea de propaganda política entre las jóvenes. La Comisión electoral Femenina del radio de Cuatro Caminos, en Madrid, invitaba a «todas las mujeres antifascistas que quieran ayudar a esta Comisión electoral, se dirijan al local de Izquierda Republicana, Bravo Murillo 127»32. Y eran conscientes, aquellas mujeres, de la importancia de la tarea que desarrollaban. Mundo Obrero, con fecha 29 de enero de 1936, publicaba una entrevista a Lina Odena, la dirigente nacional de las Juventudes Socialistas Unificadas (JSU) ya mencionada, en la que, preguntada a propósito de la naturaleza de su labor, respondía a un periodista: «¿Cómo..? Organizando brigadas de muchachas que lleven a todos los rincones la voz libertadora del Frente Popular». El semanario Estampa aclaraba ante el comienzo de los preparativos para la campaña electoral que «no sólo son hombres los que luchan. En todos los partidos, en todas las agrupaciones políticas, un ejército de mujeres presta su concurso para el triunfo de sus ideales ciudadanos... Derechas e izquierdas afilan sus armas para la pelea, en la que las mujeres han venido a ocupar los puestos de vanguardia»34.

Pero esa activa implicación en la lucha ideológica y política no era privativa exclusivamente de la izquierda. Vanguardia o no realmente, a su vez las mujeres de

29 Política, 26/1/1936, p. 4.

30 LILLO, M., «La primera abogada de Asturias», Estampa, 18/1/1936.

31 RAMOS, J. y ROSA, C. de la, «Las muchachas en la pelea», Estampa, 25/1/1936.

32 Propaganda política, octavilla. AHPCE, Sección Documentos PCE, Film XV (189).

33 ODENA, L., «Nosotras, las muchachas... también lucharemos por el triunfo del Frente Popular», Mundo Obrero, 29/1/1936, p. 4.

34 RAMOS, J. y ROSA, C. de la, «Las muchachas en la pelea», Estampa, 25/1/1936. 
Acción Popular participan en la comprobación del censo y en variadas tareas electorales en las diversas secciones, tareas como petición y recogida de «donativos», «alfabetización» e «iluminación», y lo hacen desde las oficinas que el partido de la derecha tiene instaladas en la calle de Serrano, en Madrid. Las mujeres de Falange cooperan a su vez activamente en las tareas de movilización social y de agitación propagandística a favor de las candidaturas conservadoras y ultramontanas, y lo hacen desde los locales que su partido tiene instalados en los salones de la Cuesta de Santo Domingo en Madrid, destacándose el envío que realizan de "cien mil manifiestos y cartas con instrucciones electorales a toda España». En las oficinas de Izquierda Republicana (IR), las militantes «resuelven por teléfono las consultas de los afiliados» ${ }^{35}$.

La Unión Republicana Femenina (URF) celebraría el 10 de enero de 1936, en la Casa de la República (calle de la Palma 50, de Madrid) una reunión con el objeto de fijar su posición ante las elecciones ${ }^{36}$. Pocos días después, la URF organizó un mitin en la citada Casa de la República en el que las mujeres de dicha formación se adhirieron al programa de gobierno del Frente Popular, subscribiendo los catorce puntos del manifiesto electoral en todos sus términos. En aquel mitin se pidió ardientemente a las mujeres republicanas que votaran íntegramente las listas electorales que presentaba el frente de izquierdas, porque «la izquierda es libertad, bienestar, progreso y la derecha inquisición, miseria y esclavitud» ${ }^{37}$. Pero de nuevo se invocará a los hijos, su futuro y su felicidad, como razón de ser de aquella batalla liberadora: «Acordaos de vuestros hijos asesinados en Filipinas, Cuba, África y Asturias, y evitad con vuestro voto que estos horrores sangrientos se repitan». El 18 de enero de 1936, la URF enviaba una carta al Comité electoral del Partido Socialista en la que se decía expresamente que «las reivindicaciones femeninas sólo tienen un cauce para discurrir y lograrse, y es el triunfo y el establecimiento de situaciones políticas avanzadas", y pedía que se incluyese a su fundadora y presidenta, Clara Campoamor, en las listas electorales ${ }^{38}$. Sin embargo, el Frente Popular le denegó entonces el acta electoral. Cuando Clara Campoamor solicitó su ingresó en las filas de IR, la militante fue rechazada. Un día más tarde, Política publicaba un fragmento del manifiesto de la Agrupación de Mujeres Republicanas: “iMujer, tienes en tus manos el porvenir de tu patria, el porvenir de tus hijos... iMujer: no dejes paso a las ejecuciones, al fanatismo, al atraso, y no hagas que de nuevo pueda cumplirse el doloroso pronóstico!»39.

La Asociación de Obreros y Obreras de la Aguja de Madrid (UGT) acordó, finalmente, hacer una campaña electoral exclusivamente dedicada a las mujeres,

\footnotetext{
35 «Las muchachas en la pelea», Estampa, 25/1/1936.

36 Política, 11/1/1936, p. 5.

37 «Agrupación de mujeres republicanas de izquierda», Mundo Obrero, 24/1/1936, p. 4.

38 Archivo de la Fundación Pablo Iglesias, Agrupación Socialista Madrileña. AFPI, AASM, 507-22.

39 Política, 19/1/1936, p. 5. Firmaban el manifiesto la presidenta, Blanca R. Fontecha, y la secretaria,
} A. Alonso. 
para que éstas pudieran informarse, dado que en el extrarradio madrileño, «rara es la que puede llegar a escuchar alguno de los interesantes actos que se celebran en el centro de Madrid» ${ }^{40}$. Influiría también en la realización particularizada de actos de propaganda electoral la creencia (que ya era de la época) de que una de las causas de la derrota electoral de las izquierdas en 1933 había sido la orientación del voto femenino, favorable a las candidaturas de derechas.

La Asociación de Obreros y Obreras de la Aguja organizó así actos electorales en los círculos socialistas de barriada, en los que participaron representantes de esta asociación, del PSOE y de la UGT ${ }^{41}$. Las integrantes de la Agrupación Femenina Socialista Madrileña, a su vez, prefirieron la convocatoria de mítines y reuniones diversas, en la que sus principales figuras (Margarita Nelken, Matilde Huici, María Lejárraga, etc.) «disertan una y otra vez tratando de familiarizar a la mujer con sus ideales, y hacerle comprender la obligación que tienen de votar a los socialistas, pues a ellos les debe el voto y reconocimiento de su personalidad política»42. Basaron fundamentalmente sus campañas en cuestiones de naturaleza económica y en todo aquello relacionado con la lucha política clásica. Las trabajadoras, al igual que los trabajadores, deberían tomar parte en el movimiento emancipador.

Mujeres que se involucran así en la campaña electoral, recorriendo todo el país, impulsando y encabezando numerosos actos, proclamando su apoyo a la democracia. La campaña electoral del año 36 hizó visible su protagonismo y su liderazgo político. Política destaca la afluencia masiva de mujeres al acto celebrado por IR en el cine de la localidad de Ortuella, en Bilbao, el 22 de enero de 1936, al que acudió «enorme cantidad de público, sobre todo de mineros llegados a pie desde la cuenca, en especial de mujeres» ${ }^{43}$.

El 6 de enero de 1936 las Juventudes Comunistas Sevillanas organizaron en el Teatro Bretón de Sevilla un acto contra el fascismo y la guerra, en el que intervinieron María García, Segismundo Álvarez, Luis Campo-Redondo, Cayetano Bolívar y José Ochoa, defendiendo la unión con los partidos de izquierda para impedir el triunfo del fascismo. El 6 de enero se celebró en el Cinema Europa de Madrid un acto organizado por el Grupo Sindical de Dependientes Municipales (UGT), en el que bajo la presidencia de Cirilo López, y con la asistencia destacada de Julio Álvarez del Vayo y Julia Álvarez, se defiende la unión con los partidos de izquierdas. Ese mismo día, en la Casa del Pueblo de Carabanchel Bajo, en el sur de Madrid, tuvo lugar un acto organizado por la Agrupación Socialista de la localidad, en el que bajo la presidencia de Edmundo Domínguez y con la asistencia de María Lejárraga y de Jerónimo Bugeda, se crítica la gestión del gobierno radical-cedista

40 SOUTO, S., Poder, acción colectiva y violencia en la provincia de Madrid (1934-1936). Tesis doctoral. Madrid, Universidad Complutense, 2000, p. 579.

${ }^{41}$ Carta de 18/1/1936, proponían como oradores a Lamoneda, Julia Álvarez, Julio Álvarez del Vayo o Amós Acero. FPI, AH 72-5.

42 CAPEL, R., «Mujer y política...», op. cit., p. 197.

43 Política, 22/1/1936, p. 3. 
y se confirma la unión de las izquierdas ${ }^{44}$. El PCE envió una octavilla a las mujeres, en la que se las convocaba el día 11 de enero a un mitin en el cine Maitina: « iTrabajadores! ¡Mujeres!. Acudid todos como un solo hombre a escuchar la fácil palabra de éstos portavoces de la democracia!» ${ }^{45}$. El 15 de enero de 1936 se celebraría en el local del Puente de Vallecas, en el sur de Madrid, un acto en el que intervinieron Sinovas, una mujer de la que solo se retiene el nombre de pila, Gloria, y Alejandro García, defendiendo el programa del Frente Popular ${ }^{46}$.

El 18 de enero de 1936 se realizó un acto en el teatro Barbieri de Madrid (calle Primavera 7) organizado por IR, en el que bajo la presidencia de Carvajal, Julia Álvarez vino a decir: "Cuando la CEDA propugna la creación de sanatorios para tuberculosos, nosotros debemos decir: trabajo y pan para el obrero, único medio de poder evitar eficazmente los estragos de la tuberculosis..., la lucha electoral nos lleva a cortar el paso al fascismo y a lograr medios necesarios para el desenvolvimiento de nuestros cuadros, para mayor facilidad de la organización» ${ }^{47}$. El 18 de enero de 1936 se celebró en la Casa del Pueblo de Guadarrama, en la sierra madrileña, un acto organizado por el Frente Popular en el que, bajo la presidencia de Diosdado Martínez y con la intervención de Francisco Sebastián, Manuela Ballesteros, Ramón González, Vicente Carrizo y Luis López, se defiende la unión con los partidos de izquierda ${ }^{48}$.

Entre tanto, en Política se destaca el hecho de que las mujeres presas de Oviedo sólo pueden leer El Debate y ABC. Igualmente, Política se hacía eco el 19 de enero de 1936 del llamamiento de la Agrupación Republicana Madrileña a sus afiliadas, en que se las convocaba a una reunión con fines electorales, el 20 de enero de 1936, en el círculo de IR de la calle Mayor (número 6) ${ }^{49}$. El día 18 se realizó en Madrid un acto organizado por las Juventudes Socialistas y las Juventudes Comunistas para celebrar la llamada «Semana de las 3 eles» (iLenin, Liebchknet, Luxemburgo!), en el que bajo la presidencia de Manuel Vidal y de Lina Odena y con la intervención de Felipe Barroso, Trifón Medrano y Federico Moreno, se defiende el triunfo del Frente Popular para derrocar la República burguesa y por la implantación de un régimen socialista ${ }^{50}$. El 25 de enero de 1936 en un acto femenino de apoyo a las candidaturas del Frente Popular organizado por el Círculo Socialista de Buenavista, en Los Navalmorales (Toledo), intervino Sofía García pidiendo el voto de la mujer «por la tierra, por el pan, por la libertad». El 25 de enero de 1936 se realizó en Villa del Prado (Madrid) un acto organizado por IR, en el que intervino Julia Serrano, instando a las mujeres a cumplir sus deberes con la República ${ }^{51}$, y en otro acto de la misma formación en Valmaseda (Bilbao), intervinieron Victoriana Vela, Agustín Ibáñez, Justo D. So-

44 El Sol, 7/1/1936, p. 7.

45 Propaganda electoral, octavilla. AHPCE, Sección Documentos PCE, Film XV (189).

46 Política, 16/1/1936, p. 4.

47 El Sol, 19/1/1936, p. 5; Política, 19/1/1936, p. 2.

48 El Sol, 19/1/1936, p. 5.

49 Política, 19/1/1936, p. 2.

50 El Sol, 19/1/1936, p. 5. 
monte y Alfredo Espinosa, a favor de la unión de las izquierdas. Por su parte en la localidad de Hellín, en un acto organizado por el Frente Popular, intervienen Hurtado Gómez, Elvira Fernández, Enrique Navarro y José Prat pidiendo el voto para las candidaturas progresistas ${ }^{52}$. Los mismos oradores intervinieron el 28 en pueblos de la provincia de Albacete, entre ellos Almoguera. Antes, el 26, hubo en Madrid un acto femenino organizado por la Sección de Propaganda de la Juventud de IR, en el que intervinieron Esperanza Leal, Victoria Arizón y Rafaela Calzada, secretaria de propaganda, que insistió en pedir a las mujeres su voto ${ }^{53}$. En Llanes entre tanto la misma formación, a través de Veneranda García, ensalzando la política reformista del primer bienio, pedía el voto para salvar la República ${ }^{54}$, y en el Centro Obrero de Aranguren (Bilbao), la Agrupación Socialista de la localidad, con la presidencia de Ambrosio Garbisu y asistencia de Victoriana Vela, Manuel Asarta, Justo D. Somonte y Alfredo Espinosa, defiende también la unión. El día siguiente, 27 de enero, en apoyo a las candidaturas del Frente Popular, se reunía la Sociedad de Obreros y Obreras Cerilleros «La Justicia Social» (UGT) en la Casa del Pueblo de Carabanchel Bajo, bajo la presidencia de María de Castro, cerillera de profesión. Intervinieron entonces la secretaria de las Juventudes Comunistas Catalanas, la obrera sastra Lina Odena, por las Juventudes Comunistas; Luz García, por el Sindicato de la Aguja, y Claudia García, por la Federación del Vestido y Tocado. Todas las oradoras, sin diferencias, pidieron el voto femenino para las candidaturas de izquierda, y alertaron de las maniobras de la derecha que intentaba desviar el voto de la mujer hacia las candidaturas conservadoras. Mundo Obrero recogería después que las asistentes «ovacionaron largamente los discursos de las compañeras ${ }^{55}$. Política destaca a su vez la afluencia masiva de mujeres al acto celebrado por los republicanos en Aranjuez (Madrid) el mismo día $27^{56}$, jornada en la que también se realizó en la Casa del Pueblo de Pucheta (Bilbao) un acto organizado por el Frente Popular, en el que intervinieron Astrea Burgos, M. C. Escauriaza y Arsenio Bueno. El 28 era la localidad también bilbaína de Retuerto donde el Frente Popular llevaría a Astrea Burgos, esa vez junto a Manuel Azcona y Agustín Ibáñez ${ }^{57}$. El 28, en Calahorra, el Frente Popular, bajo la presidencia de Juan García Morales, tenía como oradores a María Lejárraga, Leandro Carro y César Luis Rubio, que criticaron duramente la actuación de los gobiernos durante el bienio radical-cedista. El sindicalista Leandro Carro pediría también que la CNT hiciera causa común con las izquierdas, y César Luis protestó por la destitución del ayuntamiento del 14 de abril de 1931, defendiendo la labor realizada al frente de la alcaldía de Calahorra y pidiendo su reposición ${ }^{58}$. El 29 de enero se celebró en Madrid un acto femenino organizado por el Círculo Socialista del Puente de Toledo, en

51 Política, 26/1/1936, p. 4.

52 El Sol, 26/1/1936, p. 5.

53 Política, 26/1/1936, p. 2.

54 El Sol, 26/1/1936, p. 5.

55 Mundo Obrero, 28/1/1936, p. 4.

56 Política, 28/1/1936, p. 3.

57 AHPCE, Sección Documentos PCE, Film XV (189).

58 Política, 28/1/1936, p. 3. 
el que bajo la presidencia de Carmen Herrero, y con la asistencia destacada de Violeta Castells, Sofía García, Remedios Sánchez y Luz García, se pediría explícitamente su voto a la mujer. El 30 de enero, en el teatro Olimpia de Logroño, intervino también María Lejárraga, instando a las mujeres para que contribuyesen al triunfo, influyendo sobre sus maridos e hijos ${ }^{59}$. Al día siguiente Mundo Obrero destacaba que las mujeres antifascistas de la Agrupación de Chamartín de la Rosa y Tetuán de las Victorias (Madrid) habían rechazado el ofrecimiento de un grupo de mujeres reaccionarias de "comprar su voto con cinco duros».

El 1 de febrero de 1936 se realizó en Madrid un mitin femenino organizado por Círculo Socialista de Cuatro Caminos, en el que intervinieron Claudina García, Sofía García, Luz Fernández, Remedios Sánchez y una trabajadora de la aguja, Fuensanta Gutiérrez, pidiendo el voto. El mismo día, en otro acto femenino de apoyo a las candidaturas del Frente Popular, organizado por el Círculo Socialista de la calle Goiri 2 (Madrid) y presidido por María Mendaña, intervinieron Luisa Alonso Martínez, Guillermina Antón de la Fuente (obrera de la aguja ella también), Luz García y Ana San Martín (por el PCE), defendiendo la unión con los partidos de la izquierda para derrotar al fascismo ${ }^{60}$. Política destacaría la afluencia masiva de mujeres al acto celebrado por IR en Madrid aquel 1 de febrero de 193661. El día 1, en el frontón de Euskalduna en Bilbao, el Frente Popular volvía a contar con Astrea Barrios, que presidió en el mitin a Victoriana Vela, Julia Serrano y Matilde Huici, quienes pidieron a las mujeres vizcaínas que demostraran su civismo votando por las candidaturas progresistas. El importe de las entradas, además de cubrir los gastos de la campaña electoral, se destinaría a beneficio de las victimas de los mineros de Octubre. El día 1 en Miranda de Ebro (Burgos), hubo otro acto del Frente Popular en el que Julia Álvarez explicaría la diferencia entre religión y clericalismo.

El 2 de febrero de 1936 se realizó en el Salón Guerrero de Madrid un acto organizado por el Comité Nacional de Mujeres Antifascistas, en el que todas las oradoras, sin diferencias, instaron a seguir el ejemplo de las mujeres asturianas, las «heroínas de octubre»62, animando a votar por el triunfo del ideal igualitario. Por su parte María Lejárraga, en un conferencia que pronunció el 3 de febrero en el teatro Trueba de San Sebastián, pidió el voto y el apoyo de las mujeres por la excarcelación de los treinta mil presos políticos ${ }^{63}$. El 5 de febrero de 1936, en el teatro Barbieri de Madrid, un mitin femenino en apoyo de las candidaturas del Frente Popular fue presidido por Catalina Salmerón, interviniendo Julia Serrano, Paquita Padín, Regina García y Carmen Meana, para defender el programa del Frente Popular e invitar a las mujeres a que le dieran su voto ${ }^{64}$. El día 8, en Bélmez, las Juventudes Socialistas y Comunistas reunieron a Juan Navas Federico y Lina Odena, instando al

59 Política, 31/1/1936, p.1.

60 El Sol, 2/2/1936.

61 Política, 2/2/1936.

62 Mundo Obrero, 3/2/1936, p. 3.

63 El Sol, 4/2/1936, p. 5.

64 El Sol, 6/2/1936, p. 3. 
triunfo frentista como medio para alcanzar el socialismo. El día 10, en Gijón, el Frente Popular contó en su mitin con Albornoz, Carlos Martínez, Emilio García, Dolores Ibárruri e Inocencio Burgos, todos ellos con discursos defensores de la unión de las izquierdas para impedir el triunfo del fascismo. El mismo día, en la Línea de la Concepción (Cádiz), intervinieron Eugenia Hernández, Anita Carrillo, José Vargas y Ángel Lera para pedir el voto para el Frente Popular, lo mismo que estaban haciendo en la Casa del Pueblo de Puerto de Santa María (Cádiz), la Srta. Torres, Federico Portillo, Florentino Oitaban, José Ramírez, Vicente Ballester, Ceferino Gómez, Ramón Mila y Ángel Madrigal. En Sevilla, entre tanto, el mitin femenino del Frente Popular contaba con Manuela Regio, Carmen Navarro, Rafaela del Moral, Pilar Cebrián y Pilar Hernández de Laforest, que unidas fuertemente instaban a las mujeres a votar las listas electorales del Frente Popular para impedir el triunfo del fascismo. El mismo día, en el Ideal Cinema de la localidad de Úbeda, intervinieron José Araca, Francisco Anguita, Alejandro Peris, Victoria Kent, candidata por IR, y Pedro Campos, en defensa de la unión de toda la izquierda con los partidos que la representaban. En Vitoria, en el acto que en esa ocasión era de responsabilidad de IR, Victoria Vela fue llamada al orden por el delegado del gobierno al referirse a la «Revolución de Asturias», lo que provocó fuertes protestas de los asistentes. Algunas incidencias empiezan a aparecer por entonces, muestra de que la tensión preelectoral crecía. En un pequeño pueblo de Teruel, Villarquemado, fue apedreado el vehículo que ocupaba la candidata tradicionalista por la provincia, María Rosa de Urraca Pastor, cuando se encontraba en gira ${ }^{65}$. El 13 de febrero, en Calatayud, en un acto organizado por el Frente Popular intervinieron José María Lamana, Josefina López, Pedro Sánchez Márquez y Manuel Tobar como oradores, atacando con virulencia a los partidos de la derecha, y en concreto a sus principales figuras, Lerroux, Gil Robles (al que atribuirán propósito de golpe de Estado) y Salazar Alonso.

La actividad desplegada era la de esperar, y prácticamente en todos los actos de la campaña intervinieron mujeres. El 13 de febrero en Sevilla, en un acto del Frente Popular, serían Jofre, Magadán, Aguilar, Pilar Hernández de Laforest, Carmen Navarro y Pilar Álvarez los oradores, instando a lograr la derrota del fascismo. En Úbeda, otro acto con Consuelo Menchero y Vicente Relaño, aboga por utilizar el voto para impedir el avance del totalitarismo ${ }^{66}$. El 14 de febrero se realizó en Alcalá de Guadaira (Sevilla) un acto femenino en apoyo de las candidaturas del Frente Popular, en el que intervinieron Ana Ponce, Pilar Hernández de Laforest, Rafaela Morón y Pilar Cebrián ${ }^{67}$. El día siguiente ya no se celebrarían mítines, puesto que se votaba el 16.

En los comicios del 36, como sabemos por estudios de sociología política electoral que encabezaron los historiadores Javier Tusell y Juan Avilés ${ }^{68}$, se pro-

65 «Incidencias», El Sol, 31/1/, p. 5.

66 El Sol, 14/2/1936, p. 4.

67 El Sol, 15/1/1936, p. 5.

68 Un análisis de las elecciones en: TUSELL, J., Las elecciones..., op. cit;; AVILÉS, J., La izquierda burguesa en la II República, Madrid, Espasa-Calpe, 1985, pp. 274-288 
duciría un aumento notable de la participación en relación con las elecciones de 1933. Pero a pesar de la mayor participación y del apasionamiento de las participantes en la campaña, la mujer en España siguió sin ejercer de forma masiva su derecho al sufragio. Apatía femenina, subordinación al varón y tradicionalismo masculino explican, grosso modo, la situación. La mujer trabajadora y residente en grandes urbes se decantó mayoritariamente por las candidaturas del Frente Popular, mientras que el voto femenino rural seguía dirigido hacia las formaciones conservadoras. Dando la razón a quienes así lo creyeran en la época, Cristina Borderías afirma que «el voto de las mujeres durante la Segunda República tiende a coincidir normalmente con el del marido» 69 .

La prensa obrera y de izquierda republicana de los días inmediatamente posteriores a las elecciones destacaba el sentido ciudadano de la mujer, su ejemplo de civismo, aplaudiendo la evidencia de su «redención» al haber colaborado en la victoria del Frente Popular. Se promueven entonces, de inmediato, homenajes a la mujer republicana en diversas ciudades españolas ${ }^{70}$. La revista teórica mensual del socialismo español, Leviatán, interpreta el voto femenino en los comicios del 36 como prueba de la madurez política alcanzada por la mujer española: «El sufragio de la mujer, según todos los datos e indicios recogidos hasta la fecha, se ha inclinado por gran número al Frente Popular. No nos sorprende... Al votar por el Octubre de la revolución española en las últimas elecciones, ha votado contra todo el calendario gregoriano de la iglesia católica; contra la Roma papal,...; contra la Roma degradada por el fascismo, y contra la Roma antigua, todavía superviviente, del Derecho patriarcal -incluida la mujer como propiedad privada de ese derecho... Hecho curioso: casi siempre los que no creen en la mujer como sujeto político revolucionario son también los que dudan de la juventud y de la clase obrera como fuerzas propulsoras del progreso histórico. $Y$, sin embargo, el porvenir -un porvenir que ya es casi presente en todas partes, y sin casi en Rusia- pertenece a los obreros, a los jóvenes y a las mujeres " ${ }^{71}$.

El optimismo por la victoria no ocultaría sin embargo en los más lúcidos, y las más conscientes, la necesidad de proseguir atentos. La abogada socialista Matilde Huici reconocerá así que, en aquellas elecciones, la mujer había demostrado su conciencia de clase, su capacitación para el ejercicio de sus derechos políticos, aunque señalaba la necesidad por parte de los partidos obreros de dedicar mayores esfuerzos a la preparación política de la mujer con el propósito de «ayudar a sus compañeros en la resolución rápida de los complejos problemas actuales» ${ }^{72}$.

Más corriente sería sin embargo el traer a la luz casos de valor ejemplar, modelos de coraje en el ejercicio de la ciudadanía. Mundo Obrero destacó en sus pá-

69 BORDERÍAS, C., Entre Líneas. Trabajo e identidad femenina en la España contemporánea: la Compañía Telefónica 1924-1980, Madrid, Icaria, 1993, p. 311.

70 El Sol, 7/3/1936, p. 3; El Socialista, 10/3/1936.

71 «La mujer y las elecciones», Leviatán, 1/3/1936, pp. 129-130.

72 HUICI, M., «Rehabilitación de la mujer», El Socialista, 1/3/1936, p. 4. 
ginas, el 5 de marzo de 1936, el heroísmo y el coraje de una mujer asturiana, María La Cueva García, a quien no importó exponer su salud para votar por la candidatura del Bloque Popular: "Hemos de resaltar el heroísmo y coraje de una compañera parada, que votó por el Bloque Popular, a pesar de haber dado a luz a una niña 48 horas antes de las elecciones y tener que andar a pie media hora de su casa al colegio. Esto lo hacen los pobres, los que sienten hambre en sus hogares, los que la burguesía rapaz y explotadora los condena a la tuberculosis, a la miseria más espantosa» ${ }^{73}$.

Además, las legislativas del 36 suponen la ridiculización de aquellos sectores socialistas que habían provocado importantes disensiones internas dentro del partido, por sus reticencias a la hora de encarar la concesión del voto femenino. Frank Jellinek, al comentar el triunfo del Frente Popular, reafirmaría su creencia en que las mujeres «ya no constituyeron la masa amorfa de patético prejuicio que el clero había puesto sobre la balanza en 1933 „74. Esta imagen de la mujer como factor determinante en el triunfo de la coalición obrero-republicana, no se ajusta del todo sin embargo a la valoración de muchas de las historiadoras ${ }^{75}$.

Con todo, es preciso reconocer que el esfuerzo propagandístico de la movilización produciría efectos lentos, pero certeros.

\section{ACCIÓN POLITICA Y SINDICACIÓN FEMENINA: CONTRIBUCIÓN A LAS LUCHAS SOCIALES DE LA PRIMAVERA DEL 36.}

En 1936, llegándose a la tercera consulta electoral de la Segunda República con un censo similar al de 1933, salieron elegidas cinco mujeres: por el PSOE Julia Álvarez (Madrid), Margarita Nelken (Badajoz) y Matilde de la Torre (Oviedo); por el PCE Dolores Ibárruri (Oviedo); por IR Victoria Kent (Jaén), y por la coalición de derechas, la CEDA, Ángeles Gil Albarellos. Perdían un escaño los socialistas (Veneranda García Manzano) en Oviedo, y otro la Minoría Agraria (Francisca Bohigas Gavilanes, que había salido elegida por León en las legislativas de 1933), para ganarlos en cambio el PCE e IR. Atendiendo a la composición socioprofesional de las diputadas, Julia Álvarez y Matilde de la Torre tienen en común el título de Magisterio, Victoria Kent es abogada, Margarita Nelken periodista y escritora, y Dolores Ibárruri la única obrera. Su primera actuación como diputada por Asturias fue sacar de la cárcel a los presos de Oviedo, y la segunda, encerrarse con los mineros en huelga en el pozo de Cadavio, de la cuenca de Sama de Langreo, como cuenta ella misma en sus memorias ${ }^{76}$.

\footnotetext{
73 «Mujeres de Asturias», Mundo Obrero, 5/3/1936, p. 5.

74 JELLINEK, F., The Civil War in Spain, Nueva York, 1969, pp. 141 y 214.

CAPEL, R. M. a , «Mujer y política ...», op. cit., p. 197.

76 IBÁRRURI, D., El único camino, op. cit., p. 331.
} 
En Oviedo, una comisión de trabajadores, al frente de la cual iba la dirigente socialista Veneranda García, se entrevistó con el gobernador, al que pidieron autorización para organizarse y para reunirse en el local del periódico Avance ${ }^{77}$. Victoria Kent sería elegida vicepresidenta en las elecciones celebradas el 13 de enero de 1936, para cubrir los cargos vacantes de IR en la Junta municipal, de Madrid. El 22 de enero de 1936 fue nombrada presidenta de Honor del Comité de Protección a los presos y sus familias, en reconocimiento de la ayuda prestada a éstos ${ }^{78}$.

Ya el 17 de febrero de 1936, al conocerse el resultado electoral, diversas manifestaciones recorrieron Madrid, pidiendo la amnistía y exigiendo el cumplimiento del programa del Frente Popular. Algunos grupos se dirigieron hacia la Puerta del Sol, donde se encontraba la cárcel Modelo, y otros se situaron frente al círculo de IR, en la calle Mayor (número 6). Varios grupos de mujeres (y se supone que estaban formados por familiares de presos) subieron desde Cuatro Caminos hasta la cárcel (en la Puerta del Sol).

El 11 de marzo de 1936, en una rueda de prensa, la diputada comunista Dolores Ibárruri respondía a la pregunta de un periodista: «¿Qué impresión le hace a usted la intervención de la mujer en la lucha política?», con una rotunda negativa a quienes habían achacado el resultado de las elecciones de 1933 a la orientación reaccionaria del voto femenino: «Discrepo en absoluto de aquellos que sostienen el criterio de que la mujer no merece el reconocimiento de sus derechos políticos. Los que atribuyen a la mujer el resultado de las elecciones de noviembre del 33 están equivocados. Aquel resultado fue debido a errores del primer bienio y a la división de las fuerzas republicanas. Ello se ha confirmado en las elecciones últimas, en las cuales la contribución femenina ha sido decisiva y se ha acentuado la rebeldía en la conciencia femenina» 79 .

La mujer corriente, la mujer del trabajo y de la casa, es por ello capaz de hacer política, de estar en ella... Pero sin duda es el de la heroína el perfil de mujer que Pasionaria prefiere. Durante su intervención en un acto organizado (el 17 de marzo de 1936) por el PCE con motivo de la celebración del 65ํaniversario de la Comuna de París, recordó a Aída Lafuente, caída al pie de su ametralladora en los combates de Asturias en Octubre de 1934, haciéndolo en los más convencionales términos retóricos: «¡Francia, Marzo de 1871, Rusia, Octubre de 1917!... Fechas simbólicas escritas con sangre de trabajadores en la historia de las luchas revolucionarias del Proletariado... iAída Lafuente, querida pequeña nuestra, que tan alto supiste poner la bandera de nuestra Juventud Comunistaj ${ }^{80}$.

\footnotetext{
77 «Obreros asturianos que quieren organizarse», El Sol, 4/1/1936, p. 5.

78 Política, 14/1/1936 y 23/1/1936.

79 Entrevista a Dolores Ibárruri, en Mundo Obrero, 12/3/1936, p. 1.

80 AHPCE, Sección Tesis y Manuscritos, carp. 39, p. 15.
} 
Para los partidos de la izquierda socialista, la situación de las mujeres en Rusia, a las que consideran «hermanas liberadas», va a ser una continuada referencia. El 8 de marzo de 1936, con motivo de la celebración del día de la Mujer Trabajadora, Dolores Ibárruri se dirigía a ellas en los siguientes términos: «Más frente a esta situación de terror y de miseria a que el fascismo conduce a la mujer, y contra la cual deben dirigirse todos los ataques y todos los esfuerzos, se alzan como faro de luz esplendorosa las conquistas de la mujer en la Unión Soviética». Era la recompensa a su participación en la vida pública según las instrucciones del partido: "Ellas lucharon al lado del hombre y sus esfuerzos y sacrificios no fueron estériles. Las mujeres ocupan puestos preeminentes en la Gobernación del país, en las ciencias, en las artes, en el trabajo; las mujeres se hallan protegidas por una legislación social formidable que las pone a cubierto de toda clase de peligros». Animó a esas mismas mujeres a celebrar mítines por todo el país: « ¡Qué el día 8 de marzo no quede un solo pueblo donde no se celebre un mitin, una manifestación, un acto cualquiera que refleje la voluntad de lucha de la mujer trabajadora! ${ }^{81}$.

La estrategia y la táctica política desarrolladas por el PCE en la primavera de 1936, como señalara la propia Dolores Ibárruri en reiteradas ocasiones, conjugaba la intensa actividad de movilización en la calle para unir y movilizar a las masas, con una enérgica actividad desde el Parlamento: «Nuestra política en la calle diferirá de la de los otros grupos, procuraremos enlazar la acción parlamentaria con la lucha en la calle»82. En mayo de 1936, en un acto público, Ibárruri alertaba contra el claro peligro de reacción: «Mantened la pólvora seca y dormid con los ojos abiertos, que el enemigo acecha, y debemos estar prevenidos» ${ }^{83}$. Un mes más tarde, el 8 de abril de 1936, las militantes comunistas de la localidad de Majadahonda (Madrid) rotularon una calle con el nombre de Dolores Ibárruriri4.

Con motivo de la celebración del 1ํ de Mayo de 1936 Dolores Ibárruri se dirigiría a las mujeres, en los siguientes términos: « ¡Contra el fascismo, contra la guerra, por nuestros derechos y en defensa de la Unión Soviética, patria del proletariado, único pueblo en donde la mujer es igual al hombre. ¡Adelante. Adelante!»85. Con igual motivo, la Comisión femenina del Radio Sur de Madrid (del PCE) habló así a las trabajadoras: «iMujeres Obreras!: Este 1ํ de Mayo marca una fecha decisiva en la vida de las mujeres proletarias... Después de las jornadas de Octubre y de la ofensiva que los capitalistas industriales llevan contra nosotros en los lugares de trabajo, no podemos las mujeres permanecer al margen de la lucha». Asimismo dijeron: «Ni una sola obrera de las fábricas debe de dejar de participar el 1은 de Mayo en su defensa propia, en ello nos va la vida de los nuestros. Acudid todas,

81 AHPCE, Sección Documentos PCE, Film XIV (183). Mujeres, extraordinario de 8/3/1936, incluye además de artículos de Clara Zetkin, M. ${ }^{a}$ Teresa León, D. Ibárruri, etc, información sobre cómo viven las mujeres de la Unión Soviética.

82 Entrevista a Dolores Ibárruri, en Mundo Obrero, 12/3/1936, p. 1.

83 IBÁRRURI, D., El único camino, op. cit., p. 329.

${ }_{84}$ Mundo Obrero, 9/4/1936, p. 1.

85 Mundo Obrero, suplemento al extraordinario de $1^{\circ}$ de Mayo de 1936. 
como una sola, a la gran manifestación que el Partido Comunista prepara a las 10 de la mañana el día $1^{\circ}$ de Mayo, en la glorieta de Bilbao. ¡Abajo la guerra!. ¡Abajo el fascismo! ¡Viva el $1^{\circ}$ de mayo Rojo! ’ ${ }^{86}$. La diputada socialista Margarita Nelken intervino (el 1 de mayo de 1936) en un acto en la plaza de Toros, de Valencia, junto con Antonio Mije, por el PCE, y José Gregor, por las JSU. Nelken intervino también en otro mitin en Alcira junto con Antonio Mije y Carlos Hernández Zancajo el mismo día. En Cádiz intervino Anita Carrillo junto con Martín Parapat, por el PCE; José Prat, por la UGT, y Fernández Ballestero, por el PSOE ${ }^{87}$. Se nombraron ese día varias calles con el nombre de Aída Lafuente: una en Játiva y otra en Málaga, esta última en sustitución de un nombre tradicional, el de calle del Carmen.

La actuación de la diputada Dolores Ibárruri fue intensa en el Parlamento, en el que realizó numerosas y acaloradas intervenciones, desde la discusión de las actas de Salamanca en el mes de abril de 1936, hasta la que llevó a cabo el 16 junio de $1936^{88}$, con motivo del debate sobre la situación del orden público, siendo ésta última la más sonada. Allí afirmó «que se preparaban ya los funerales de la democracia». A la pregunta de «¿Por qué se producen las huelgas?», la diputada Ibárruri contestaba enérgicamente: «Ellas no representan más que el deseo de mejorar su situación y de hacer menos profunda la miseria en que viven» ${ }^{89}$.

En sus memorias, Dolores Ibárruri hace referencia a su intervención afirmando que sus «palabras, expresión de la política y de la oposición del PCE, hallaron una aprobación clamorosa en todo el país». De todas sus intervenciones, además de las habidas en el Parlamento, la más sonora fue la que hizo al día siguiente de la sublevación militar por los micrófonos del Ministerio de la Gobernación: « ¡El fascismo no pasará! ¡No pasarán los verdugos de octubre! ¡No pasarán!»90, grito de guerra desde entonces para todos y todas los combatientes por la libertad. Pero también la del 29 de julio de 1936, dirigida a todos los trabajadores de Europa, animando a defender la democracia ${ }^{91}$.

En el número de la revista Mujeres inmediatamente anterior al alzamiento militar, la diputada comunista hace un llamamiento a todas las mujeres antifascistas para «luchar por conseguir el reconocimiento de su personalidad como mujer», enumerando una serie amplia de reivindicaciones: «El derecho al trabajo; la igualdad de salarios; la protección a la madre; la investigación de la paternidad; el divorcio sin ninguna traba jurídica ni económica; el derecho al aborto; la creación de casas-cunas, jardines de la infancia, escuelas, comedores y roperos escolares; la

\footnotetext{
${ }^{86}$ AHPCE, Sección Documentos PCE, Film (173).

87 Solidaridad Obrera, 3/5/1936, p. 3.

88 DSC, 3 de abril de 1936. PRIETO, I., «En el Parlamento ha entrado una mujer», El Liberal (Bilbao), 4/4/1936.

89 DSC, 16 de junio de 1936

90 Folleto que contiene el artículo de Dolores Ibárruri: «Los fascistas no pasarán», en AHPCE, Sección folletos y octavillas, 1936, sig. 13/1.3.2.

91 USANDIZAGA, A., Ve y cuenta lo que pasó en España: mujeres extranjeras en la Guerra Civil: una antología, Barcelona, Planeta, 2000.
} 
prohibición de trabajos insalubres y el derecho a ocupar cargos, en lícita competencia con los hombres»92. Mundo Obrero se hacía eco el 14 de mayo de 1936 del llamamiento del Comité Nacional de Mujeres Antifascistas a las mujeres, invitándolas a entrar en su organización, «cuyo fin primordial es, como indica su nombre, luchar contra estos dos peligros que acechan a los pueblos: el fascismo y la guerra». De cara a sus propias tareas, el Comité animaba a la acción: "Nosotras tenemos también que desarrollar, al mismo tiempo, la conciencia política de la mujer», para cumplir así los objetivos básicos: «La lucha contra el fascismo, la lucha contra la guerra y la educación política, social y cultural y artística de la mujer, tal es nuestro programa, tales son nuestros propósitos» ${ }^{93}$. Su objetivo era integrar a las mujeres en la causa antifascista y, al mismo tiempo, promocionar al PCE entre las mujeres ${ }^{94}$. El 21 de mayo de 1936 una comisión de trescientas militantes comunistas encabezada por la propia Ibárruri, se personó en la embajada de Brasil para hacer entrega de tres mil firmas, entrevistándose con el mismo secretario de la embajada, al que exigieron la liberación inmediata de Luis Carlos Prestes ${ }^{95}$.

Por el contrario, las diputadas que menos intervenciones tuvieron en las Cortes fueron las socialistas Julia Álvarez ${ }^{96}$ y Victoria Kent, que no llegó a tener ninguna participación en las Cortes de 1936 ${ }^{97}$. La diputada socialista Margarita Nelken intervino muchas veces en las sesiones, tomando parte en los asuntos de Instrucción Pública ${ }^{98}$, en el debate sobre las bases de trabajo y política social circunscritos a la provincia de Badajoz, por la que había salido elegida diputada; pretendiendo el rescate de los bienes comunales de los municipios para entregarlos a los campesinos desempleados, lo que la enfrentó directamente a la derecha. Nelken fue siempre crítica respecto a la política de orden público, lo que no gustó tampoco a los republicanos y socialistas.

Matilde de la Torre, por su parte, se destacó dentro del PSOE por sus dotes de oratoria. El 15 de abril de 1936 la minoría socialista la designaba representante del partido en la comisión parlamentaria de Marina ${ }^{99}$. Pocas veces dejó oír su voz en el Parlamento, sin embargo; aparecerá, con todo, defendiendo la postura de su partido al debatir la cuestión religiosa, oponiéndose rotundamente a la amnistía para las derechas así como a la política de construcciones navales que se estaba ini-

92 Mujeres, 3 mayo de 1936, p. 2.

93 «Un llamamiento del Comité de mujeres contra la guerra», Mundo Obrero, 14/5/1936, p. 6.

94 «Mujeres de Madrid preparaos a vencer», Mundo Obrero, 29/10/1936, p. 3.

95 Mundo Obrero, 18/5/1936, p. 6 y 22/5/1936, p. 3.

96 GARCÍA, E., La actuación de la mujer en las Cortes de la II República, Madrid, Almena, 1979, p. 172.

97 FRANCO, G., «La contribución de la mujer española a la política contemporánea: de la Restauración a la Guerra Civil (1876-1939)», en M. A. DURÁN et al., Mujer y sociedad en España: 1700-1975, Madrid, Ministerio de Cultura, Dirección General de Juventud y Promoción Socio-Cultural, 1986, p. 256.

98 Victoria Kent sería designada representante socialista en la comisión de Instrucción Pública. El Sol, 16/4/1936, p. 4.

99 «Designación de representantes socialistas en las comisiones parlamentarias», El Sol, 16/4/1936, p. 4. 
ciando. También hubo candidatas no elegidas, tradicionalistas como Pilar Careaga y María Rosa de Urraca Pastor, y republicanas, como María de Maeztu100. Aunque no fueron elegidas, desarrollaron una tarea de movilización política. Rosa de Urraca Pastor formará parte del Consejo Nacional de Falange.

Pero más allá de las actuaciones individuales, más fáciles de reconstruir, estarían las acciones colectivas ${ }^{101}$. Movilizaciones que a partir de entonces cobrarán un signo democrático e igualitario.

Es destacable su creciente influencia en el entorno sindical, siendo víctima por este motivo de la represión franquista posterior ${ }^{102}$.

La participación de las mujeres en las luchas sociales obedece en general a móviles comunes, la condición de clase y su inserción en las luchas sindicales, pero suele presentarse además en relación directa con la defensa de las condiciones de vida familiares. Lo cual provoca una toma de conciencia dual, que refuerza la doble identidad de la mujer trabajadora como «proletaria» y "ama de casa».

EI PCE envío una circular a las mujeres que trabajaban en la fábricas de membrillo, en las que se las insta a exigir un salario de 50 pesetas y una jornada laboral de 8 horas: " $i$ Mujeres que trabajáis en fábricas de membrillos!: Es preciso, que desde ahora os pongáis // de acuerdo para conseguir salarios decorosos, // ya llevamos unos días que los patronos y // empresarios vienen dando el mismo salario // mientras la carestía de la vida ha aumentado // considerablemente. // Hablar unas con otras y poneros de acuerdo // en el salario que habéis de pedir antes de // que empiece la campaña, manteneros unidas // hasta conseguir lo que es vuestro y os pertenece // por vuestro trabajo (el pan de vuestros hijos). // iPor un salario mínimo de 50 pesetas para // las mujeres y los jóvenes en 8 horas de trabajo! // ;Que nadie toque a una máquina ni entre // por las puertas de las fábricas, sin antes haber // conseguido esta justa reivindicación! // iTodas unidas hasta conseguirlo» ${ }^{103}$.

Las mujeres llevaron a cabo actos de violencia desesperados. EI PCE envió una octavilla dirigida a las trabajadoras, instándolas a tomar por asalto las tahonas, siguiendo el ejemplo de las mujeres asturianas y barcelonesas ${ }^{104}$. La secuencia es constante. Pero será la Guerra Civil el crisol de la movilización femenina por excelencia, precedida de acciones, muchas de ellas todavía del tipo antiguo de motín de subsistencia.

100 GARCÍA, E., La actuación de la mujer...., op. cit, p. 47.

101 MORAL, M. del, «Transgresión parcial y transgresión global en la acción colectiva femenina», XIII Coloquio Internacional de la AEIHM, 2006.

102 CAPEL R. M. a, «De protagonistas a represaliadas: la experiencia de las mujeres republicanas», Cuadernos de Historia Contemporánea, volumen extraordinario 11/12 (2007), pp. 35-46.

103 Panfleto, s.f. AHPCE, Sección Organización de Mujeres, Caja 118, carp. 10.

104 Panfleto, s. f. AHPCE, Sección Organización de Mujeres, caja 118, carp. 10. 
El 1 de marzo de 1936 las mujeres se manifestaron por las calles de Teruel, pedían la rebaja de 15 céntimos en el precio del kilo de pan ${ }^{105}$. El 7 de mayo de 1936, una comisión de mujeres de la localidad de las Rozas de Valdearroyo, en Santander, "que hicieron el viaje con billete de la caridad», se dirigen en manifestación al Ministerio de Obras Públicas en Madrid, entrevistándose con el Director general y hasta con el mismo Ministro, a los que expusieron la situación de «mayor miseria» en la que se encontraban seiscientas familias como consecuencia de la paralización de las obras del pantano del Ebro ${ }^{106}$. El 17 de mayo de 1936, en una aguda crisis de trabajo, más de setecientas mujeres y niños se dirigen en manifestación a la alcaldía de Alhama, en Granada, para protestar por la angustiosa situación en la que se hallaban, agravada por la subida del precio del pan ${ }^{107}$.

La variable «clase» se superpone así a la variable «género», como ha sido puesto de relieve en la historiografía ${ }^{108}$.

A través de la prensa y de la documentación interna de los partidos y sindicatos obreros, se constata un incremento significativo de la sindicación femenina al movimiento obrero. Como ejemplo se podría citar la incorporación de las obreras de Granada - sirvientas, sastras, camareras y chocolateras- a las diferentes secciones de los sindicatos de la CNT, y el de las trabajadoras de Miranda de Ebro al Sindicato Único en marzo de $1936^{109}$. Esta actividad suscitaría conflictos intersindicales. Solidaridad Obrera denunciaba desde sus páginas el 12 de mayo de 1936, el comportamiento desleal de ciertos militantes socialistas.

El semanario Estampa informaba de la constitución de una Sociedad de Obreros y Obreras del Servicio Doméstico en Cádiz, sector que empleaba en la provincia a unas tres mil mujeres, y de la afiliación a la citada sociedad en el primer mes de su constitución, de más de seiscientas trabajadoras. La sociedad había sido creada por iniciativa de Crisanto Bravo, camarero del Café Novelty y antiguo militante. El 4 de abril de 1936, en una entrevista publicada por Estampa, la vicepresidenta de sociedad, Ana Romero, respondía a la pregunta de un periodista: « ¿Pero qué es lo que quieren ustedes?», en los siguientes términos: "Todavía no tenemos confeccionadas nuestras bases. Pero, en primer lugar, queremos elevar el nivel moral del gremio que ha vivido siempre en la sombra, postergado y explotado. Luego, en las mejoras mínimas que solicitamos, entran el aumento de sueldo — que cada criada gane, como mínimo, de dieciséis a veinte duros mensuales-, jornada de ocho horas continua o alterna, el descanso semanal, la legislación sobre accidentes de nuestro gremio y el seguro de maternidad „110. La aparición entonces de asociacio-

105 El Sol, 2/3/1936, p. 1

106 Solidaridad Obrera, 8/5/1936.

107 El Socialista, 18/5/1936.

108 La movilización social en NASH, M., Mujer y movimiento obrero..., op. cit.

109 MORALES, A, «La mujer acude a los sindicatos. Jornada de un movimiento femenino», Solidaridad Obrera, 12/3/1936; CLEMENTE, J., «Las mujeres trabajadoras de Miranda de Ebro», Solidaridad Obrera, 12/3/1936.

110 «Las sirvientas de Cádiz, bajo la bandera roja y negra», Estampa, 4/4/1936. 
nes de trabajadoras domésticas puede ser un síntoma, y, así se interpreta, de un cierto avance del anarquismo en un terreno de tan difícil sindicación.

Es patente el crecimiento de la UGT según los datos de las actas ${ }^{111}$ de las reuniones de los comités nacionales de las federaciones de industria. Entre 1931 y 1936 se constata el ingreso de 11.954 mujeres en un total de 189 asociaciones. Cuatro de éstas ingresan y reingresan en la UGT durante éstos años: la de Cerilleras de Tarazona (Zaragoza), con 95 afiliadas (reingresaba en mayo de 1936), la Obrera Femenina en Arte de la Seda de Gandía (Valencia), la Sociedad de Obreros y Obreras de la fábrica de Lozas de Carabanchel Bajo (Madrid) y la Obrera Femenina de Hondón de las Nieves (Alicante). Entre las bajas se cuentan la Sociedad Femenina El Porvenir de Plasencia (Cáceres), con 100 afiliadas, y Tabaqueras Vindicación de Logroño (sus integrantes ingresarán en oficios varios en 1933). El 15 de abril de 1936, en una reunión del comité ejecutivo, las Obreras del Azúcar, con 64 afiliadas, solicitaban el ingreso en esta federación. En una reunión posterior de la comisión ejecutiva de la Federación del Vestido y el Tocado, celebrada el 22 de abril en la localidad de Pasajes, y por mediación de la Federación de Guipúzcoa, solicitaban ingresar en dicha federación. Asimismo, las obreras corseteras de Zaragoza, y por mediación de la Federación local de sindicatos, pedían entrar en la federación ${ }^{112}$. El «compañero» Rafael Cruz era enviado a Barcelona para que hiciese cuantas gestiones le fuese posible, encaminadas a lograr el ingreso de las secciones de la Aguja de esta localidad ${ }^{113}$. En mayo de 1936, asimismo, ingresaron (de Productos Químicos) La Unión, la Sociedad de Cerilleras de Moncayo, con 534 afiliadas $^{114}$, y La Justicia Social, cerilleras de Tarazona, con 95.

Por entonces, encontramos sindicatos socialistas con trabajadoras afiliadas en Madrid ${ }^{115}$ : así la Sociedad de Cerilleras de Carabanchel Bajo «La República», la Sociedad de Obreros y Obreras Locistas de Carabanchel Bajo, la Sociedad de Lamparilleras (enero 1936), con 12 afiliadas, la Sociedad de los Obreros del Hospital Militar de Carabanchel Bajo (abril 1936), la de Repartidores de Leche (mayo 1936), con 7 afiliadas, la Sociedad de Traperos (mayo 1936), con 212 sindicadas, la Sociedad de Oficios Varios de Robledo de Chavela (mayo 1936), con 1 afiliada, la Femenina de Trabajadores de la Tierra de Villa de Prado (junio 1936), con 96, la Sociedad de Obreros y Obreras del Hogar, Obreros de la Compañía Arrendataria de Fósforos (junio 1936), y el Sindicato de Empleados de Manicomios y Hospitales de Leganés (julio 1936), con 32 afiliadas. El presidente de la Agrupación Socialista de Los Rosales (Sevilla), Antonio Valdivia, refiriéndose a ésta afirmaba el día de

\footnotetext{
111 Lo que se puede seguir a través de la sección fija de el periódico El Socialista, «Federaciones». Véase «Militantes del P. C. en marzo de 1936» y «Militantes del Partido en julio de 1936». AHPCE, Sección Documentos PCE, carp. 17. Sobre la implantación, TUÑÓN DE LARA, M., El movimiento obrero en la historia de España, Madrid, Taurus, 1972.

112 «Federaciones», El Socialista, 17/4/1936, p. 5

113 «Federaciones», El Socialista, 23/4/1936, p. 5.

114 «Federaciones», El Socialista, 6/5/1936, p. 5.

115 Datos de la historiadora Gloria NÚÑEZ, «La presencia de las trabajadoras en la UGT, 1931-1936», Estudios de Historia Social 42-43 (julio-diciembre 1987), pp. 264-269 y 270-272.
} 
la sublevación militar en Claridad, que no contaba «más que con mujeres»116 (tenía 80 obreras afiliadas).

Entre la nómina de líderes sindicales y obreras se cuentan también algunos de los nombres más conocidos de la España del primer cuarto del siglo XX: la trabajadora del textil, la socialista y autodidacta María Cambrils, las abogadas socialistas Matilde Huici y Matilde Cantos, Victoria Kent. Pero el caso de Dolores Ibárruri, Pasionaria, es de todos el de mayor relieve.

Dolores Ibárruri, nacida en el seno de una familia minera de la localidad de Gallarta, desde las filas de la agrupación socialista de Somorrostro derivó al comunismo. En 1920 fue nombrada miembro del comité provincial de Vizcaya del PCE, y fue elegida delegada al I Congreso del PCE celebrado en marzo de 1922. Comenzando a colaborar en La Bandera Roja (primer periódico del partido en Vizcaya), será miembro del Comité Central del PCE desde 1930 y delegada del comité provincial de Vizcaya a la Conferencia del partido celebrada en Pamplona en 1930. Desde 1931 trabajó en Madrid en la redacción de Mundo Obrero'17, siendo reelegida miembro del Comité Central en el IV Congreso celebrado en Sevilla en marzo de 1932, y en el cual fue reemplazado el equipo de José Bullejos por el de José Díaz Ramos. Por entonces fue encarcelada, igual que lo había estado antes y lo volvería a estar después. En 1933 creó, bajo los auspicios del PCE, la Agrupación de Mujeres Antifascistas (AMA) ${ }^{118}$, y en 1934 Socorro Rojo Internacional. Fue tal su éxito en Asturias que el PCE la nombró candidata para la región ${ }^{119}$.

Son igualmente relevantes Irene Falcón, que sentó las bases del movimiento teórico feminista; Encarnación Sierra, María Luisa Navarro Margati (fundó la Agrupación Femenina Republicana, en pro de los derechos de los niños y de la mujer).

A los nombres ya mencionados deben sumarse los de Rosario Dulcet (una militante muy activa del Sindicato Textil y Fabril de Barcelona); Concha Pérez (única mujer que integrara la Junta directiva del Sindicato de Artes Blancas de la CNT, de Barcelona), comentaría después de la guerra: «En el sindicato había muy pocas mujeres y menos en la $F A$ /»; Concha Liaño, que era hija del anarquista Ricardo Liaño, quien escribía regularmente una columna en Solidaridad Obrera titulada «Aguafuerte» (pseudónimo de Hermes). Llum Quiñonero la recuerda así en su obra recientemente editada, Nosotras que perdimos la paz: "Si había una huelga, una movilización, un debate allí estaba Conchita»120.

116 Claridad, 18/7/1936, p.7

117 Artículos de Dolores Ibárruri correspondientes a los años 1932-1934, en AHPCE, Sección Dirigentes, sig. 13/1.3.1.

${ }_{118}$ EI PCE tuvo gran influencia en su dirección y orientación. De hecho, Dolores Ibárruri presidía el Comité Nacional y a lo largo de su existencia, las tres secretarias generales también fueron militantes comunistas: Lina Odena, Encarnación Fuyola y Emilia Elías.

${ }_{119}$ Una síntesis biográfica sobre ella, en PRESTON, P., Las tres españas del 36: una revisión radicalmente distinta y original de la compleja trama de la guerra civil española, Barcelona, Plana \& Janés, 1998.

120 QUIÑONERO, L., Nosotras que perdimos la paz, Madrid, Foca, 2005, p. 114 y p. 263. 
Las batallas de Federica Montseny oscilaron entre el ámbito doméstico, donde perseguía en la vida cotidiana un trato igualitario con el hombre y romper con la tradicional postergación de la mujer, y el público, donde se volcó a través de la labor editorial de sus padres, Federico Urales (Juan Montseny) y Soledad Gustavo, a publicitar a través de revistas, novelas, cuentos y ensayos las ideas libertarias. Bajo la Dictadura de Miguel Primo de Rivera se convirtió en un activo miembro de la FAI. Afiliada a la CNT, formó parte del comité de la Confederación Regional del Trabajo de Cataluña. Aceptó formar parte del gobierno que Largo Caballero formó en noviembre de 1936, encargándose de la recién creada cartera de Sanidad y Asuntos Sociales ${ }^{121}$, siendo la primera mujer ministro. «Una mujer de voluntad de roca, que no se tuerce, y de carácter de hierro, que no se rompe». Así se definió a sí misma una tenaz luchadora. Lucía Sánchez Saornil122, telefonista, autodidacta, afiliada a la CNT desde 1931, que fundó, junto con Mercedes Comaposada y Amparo Poch y Gascón, la organización feminista y anarquista Mujeres Libres ${ }^{123}$.

Sin que podamos detenernos aquí en sus biografías y actuaciones, citaremos también a Isabel Oyarzábal de Palencia, María Zambrano, Francisca Benaigues, Rosario de Acuña, Sara Berenguer, Lola Iturbe, quien dirigió, junto a su compañero Juan Manuel Molina, el periódico Tierra y Libertad; Aurora Rodríguez Carballeira, que constituye un caso extremo de dedicación a la formación intelectual de su hija Hildegart ${ }^{124}$, junto a otras mujeres menos conocidas más tarde, invisibles por el momento para el discurso histórico y, pese a todo, activas y reales.

El 17 de febrero de 1936 el jefe de gobierno, Portela Valladares, decretó el estado de alarma, por temor a un golpe de la derecha. El día 19, Portela dimitió, traspasando los poderes a Azaña. De nuevo en el poder, los republicanos de izquierda reemprendieron la política reformista del primer bienio. Indalecio Prieto fue partidario de reformar el sistema social desde el propio gobierno con la colabora-

121 MONTSENY, F., Mi experiencia en el Ministerio de Sanidad y Asistencia Social: Conferencia pronunciada el 6 de junio de 1937 en el Teatro Apolo, Valencia, Comisión de Propaganda y Prensa del Comité Nacional de la C.N.T., 1937. Una síntesis biográfica sobre ella, en la introducción de Alicia LANGA a la novela La indomable, Madrid, Castalia, 1991, pp. 7-42; ALCALDE, C., Federica Montseny: palabra en rojo y negro, Barcelona, Argos Vergara, 1983; MARTíN, E., Federica Montseny, Barcelona, Labor, 1992; AYMERICH, P., PESSARRODONA, M., Federica Montseny: un retrat, Barcelona, Institut Català de la Dona, 1998; LOZANO I, Federica Montseny. Una anarquista en el Poder, Madrid, Espasa-Calpe, 2005; TAVERA S., Federica Montseny. La indomable, Madrid, Temas de Hoy, 2005. Todos los estudios coinciden en señalar que tuvo que superar muchas presiones hasta que finalmente decidió incorporarse al Gabinete socialista.

122 Lucia Sánchez trabajaba en la Compañía Telefónica durante la huelga en 1931, y por su participación en ésta fue trasladada a Valencia (ITURBE, L., La mujer en la lucha social y en la guerra civil de España, México, Editores Mexicanos Unidos 1974, p. 101).

${ }^{123}$ TAVERA, S., «Guerra Civil y anarcofeminismo. Sus antecedentes históricos», en M. $\mathrm{D}$. de la Calle y M. Redero, eds. Guerra Civil. Documentos y Memoria, Salamanca, Universidad de Salamanca, 2006, pp. 45-64.

124 Hildegart ingresó a los 14 años en las Juventudes Socialistas y en la UGT. Defendió la libertad sexual y reproductiva en obras como Paternidad voluntaria: profilaxis anticoncepcional (1931); La rebeldía sexual de la juventud (1931). En 1932 ingresó en el Partido Republicano Federal y fue nombrada secretaria de la Liga para la Reforma Sexual. Sobre su figura, E. de GUZMÁN, Aurora de sangre. Vida y muerte de Hildegart, Madrid, G. del Toro, 1972. 
ción republicana, mientras que Largo Caballero estuvo a favor de apoyar al gobierno desde el exterior.

Hay una España que sufre fuertes tensiones y que se corresponde, al parecer, con la España que vota a las izquierdas. El 21 de febrero de 1936 la Sociedad de Obreros y Obreras del Hogar (UGT) enviaba una nota a Mundo Obrero en la que se denunciaba que desde el 17 de febrero de 1936 se habían iniciado en Madrid despidos de compañeras, hechos que la citada organización relacionaba con el resultado electoral ${ }^{125}$. Lo que Azaña y el Gobierno consideraban un problema de orden público no era más, según Santos Juliá, «que el primer resultado social del triunfo político del Frente Popular en las urnas» ${ }^{126}$.

Según documentación que obra en los archivos del PCE, en el taller Carmena, propiedad de Pedro Carmena, situado en la calle Duque de Alba (Madrid), fue despedida una joven trabajadora por haber denunciado en una asamblea de la Sección de Obreros a jornal del Sindicato 'La Razón del Obrero' (UGT), que se hallaban en ellos "aprendizas adelantadas a las que se les paga con cinco y seis reales, y su jornal según bases son tres pesetas; aprendizas con una peseta y debe ser una veinticinco» ${ }^{127}$.

A través de la prensa de distintas tendencias ideológicas, se constata la existencia de violentos incidentes. La secuencia es constante ${ }^{128}$. Un grupo de trabajadoras fueron apaleadas por las fuerzas de seguridad cuando se manifestaban frente a la empresa en la que trabajaban, para protestar contra el trato vejatorio del que habían sido objeto varios compañeros en represalia por el incendio de un centro de Acción Popular, «El Cortijo» ${ }^{129}$. Un grupo de mujeres republicanas abría una suscripción, con objeto de contribuir a la reconstrucción del hogar de la esposa del filósofo Ortega y Gasset, que fue destrozado como consecuencia de la explosión de una bomba. «Las suscripciones podrán entregarse en los locales de Izquierda Radical Socialista, San Bernardo 58, de 5 de la tarde a $8{ }^{130}$. En Villena, un grupo de vendedoras de hortalizas, con motivo de una riña por ideas políticas, derribó el carro de una compañera de profesión, interviniendo la Guardia Civil para disolver la aglomeración ${ }^{131}$.

Largo Caballero recuerda en Escritos de la República, que Azaña le llamaba «todos los días para quejarse de la conducta de los trabajadores» ${ }^{132}$. La CNT no

125 «Las represalias contra las obreras del hogar», Mundo Obrero, 21/2/1936, p. 2.

126 JULIÁ, S., Manuel Azaña: una biografía política. Del Ateneo al Palacio Nacional, Madrid, Alianza Editorial, 1990, p. 459.

127 «A los obreros y obreras del Bazar El Sol, Casa Aleus y Carmena. Los Comités del Sector Sur del Vestido y Tocado de Madrid». AHPCE, Film XIV (174).

128 Sobre la conflictividad social y violencia política, AVILÉS, J., La izquierda..., op. cit., 298-304.

129 «Varias mujeres apaleadas por los guardias», Mundo Obrero, 11/3/1936, p. 1.

130 «En homenaje a la esposa de D. José Ortega y Gasset», El Sol, 10/4/1936, p. 4.

131 «Riña por cuestiones políticas», El Sol, 1/6/1936, p. 6.

132 LARGO CABALLERO, F., Escritos de la República. Notas históricas de la guerra en España (1917-1940), Madrid, Editorial Pablo Iglesias, 1985, p. 298. La oposición patronal a los Jurados Mixtos en CABRERA, M., La patronal ante la II República: organización y estrategia, Madrid, Siglo XXI de España, 1983, pp. 202-218. 
dejará de inspirar huelgas en la primavera de 1936. En 1936 la UGT era defensora de la negociación frente al modelo defendido por la patronal. La situación en el campo se deterioraba con un rápido incremento del paro. "Las campesinas de las zonas rurales intervinieron activamente en los diversos tipos de revueltas originadas en las localidades donde habitaban... Surgían por doquier „ ${ }^{133}$. Según el Boletín del Ministerio de Trabajo, el número de huelguistas fue en aumento en la primavera de 1936 (en marzo 2.505, en abril 27.828 y en junio 55.310). Las consecuencias eran graves para la izquierda, como pone de relieve Santos Juliá: «Huelgas y cierres resumen el proceso que hace perder a los partidos de la República la representación política de intereses de clase» ${ }^{134}$. La historiadora Gloria Núñez, que las revisó en su día, recuerda que «dentro del total de 4.202 huelgas ocurridas desde enero de 1931 a junio de 1936, solamente he encontrado 47 que mencionan a las obreras» ${ }^{135}$. Y suelen ser acciones defensivas. La propia estructura del empleo femenino dificultaba la agrupación sindical, y en consecuencia las movilizaciones. La cifra de conflictos muestra, según Gloria Núñez, «el grado de conciencia obrera alcanzado por las trabajadoras a pesar de que había gran cantidad de contratadas sólo por temporadas» ${ }^{136}$. Existen datos aislados de que se movilizaron en demanda de derechos específicamente femeninos ${ }^{137}$.

Mil novecientos treinta y seis comienza en Madrid con la huelga planteada en los talleres de confección Flomar s, en la Gran Vía, bajo la dirección del Sindicato «La Razón del Obrero» (UGT), en protesta por el despido de ciento veinte compañeras y por el intento del patrono de contratar «nuevo personal para rebajar los salarios y aumentar la producción ${ }^{138}$. A comienzos de enero de 1936, ciento sesenta cerilleras de Carabanchel Bajo protestaban del mal estado de los materiales porque ello entorpecía y hacía más lento el trabajo, de modo que los destajos de las llenadoras de cajas no alcanzaban la remuneración ${ }^{139}$. Las cerilleras desistieron

133 NUÑEZ, G., Trabajadoras de la Segunda República: un estudio sobre la actividad económica extradoméstica: (1931-1936), Madrid, Ministerio de Trabajo y Seguridad Social, 1989, p. 445.

134 JULIÁ S., «Gobernar, ¿Para quién?. Debilidad de partidos y representación de intereses en la II República», Revista de Derecho Político, núm. 12 (1978), p. 158. La idea de situación revolucionaria en España en los años 30 en TILLY C., Las revoluciones europeas (1492-1992), Barcelona, Crítica, 1995, pp. 106 y ss.

135 NUÑEZ, G., Trabajadoras..., op. cit., pp. 426-440. Un 43\% corresponde a móviles relacionados con la asociación y personal; un $25 \%$ se originan por motivos salariales y un $15 \%$ se promueven debido a la organización del trabajo. El sector doméstico únicamente presenta un conflicto. Un panorama muy distinto al de la manufactura del tabaco, donde la proporción de obreros en huelga sobre los ocupados asciende al 100 por 100 (NUÑEZ, G., Trabajadoras..., op. cit., p. 439).

${ }_{136}$ La provincia con mayor grado de conflictividad femenina es Madrid, con 7 huelgas, seguida de Alicante con 6, y de Barcelona con 5. En La Coruña, Asturias y Guipúzcoa se localizan 3 en cada territorio. En Sevilla y Zaragoza, donde se localizan 3 huelgas respectivamente, el sindicalismo anarquista o comunista entre las trabajadoras sería un factor coadyuvante a la conflictividad. NUÑEZ, G., Trabajadoras...., op. cit., pp. 432-434. En las zonas latifundistas del sur, el número de entidades obreras decrece, tanto por razones de tipo ideológico como social (la mayor cerrazón sociocultural del área y la conformación de un patriarcado extremo).

137 El movimiento conflictivo específicamente femenino motivado en contra de la cuota obrera al seguro de maternidad en NÚÑEZ, G., Trabajadoras..., op. cit., pp. 268-272.

138 Mundo Obrero, 17/1/1936, p. 6.

139 Ahora, órgano de la Federación Provincial de las JSU de Madrid, 11/1/1936, p. 27; El Sol, $11 / 1 / 1936$. 
de ir a la huelga, sin embargo, por estarse en periodo electoral, pero pidieron que se les pagaran los días de huelga y que, cuando pasaran las elecciones, se vigilara para corregir las infracciones de ley y que se acordaran mejores bases de trabajo $^{140}$. El 10 de marzo de 1936 paraba todo el ramo de la sastrería de Madrid ${ }^{141}$. El 17 de marzo de 1936 las obreras de los talleres de confección Flomar's podían dar por terminada la huelga al haber conseguido cuantas peticiones tenían formuladas a la dirección de la empresa. Entre ellas, destaca el compromiso de que, en el futuro, serían los sindicatos los que en exclusiva enviarían cuantos trabajadores precisara la empresa ${ }^{142}$. Entre mayo y julio de 1936 iba a agravarse el problema social.

Las operarias textiles catalanas de la Casa Baliu y Guisona, en Igualada, fueron a la huelga en protesta por la decisión patronal de cierre definitivo ${ }^{143}$. En Sevilla, las aceituneras de los almacenes de la Viuda de Diego Gómez se movilizaron contra una decisión patronal similar ${ }^{144}$. El 15 de mayo de 1936, en una reunión de la comisión ejecutiva, Claudina García, por la Federación del Vestido y Tocado, informó que los obreros de la fábrica de corsés «Viuda de Seisdedos», ante la negativa de la patronal a discutir nuevas bases de trabajo, no descartaban la posibilidad de presentarlas al delegado de Trabajo con el correspondiente oficio de huelga ${ }^{145}$. A finales de mayo de 1936, las obreras de la Sección de Tricotaje de la fábrica Quirós, bajo la dirección del Sindicato Textil (UGT), se declararon en huelga en protesta por el despido de una compañera, y «exigen terminar con los salarios de hambre que existen en la actualidad» ${ }^{146}$. El conflicto surgió al negarse el patrono a la discusión de unas bases que estaban muy por debajo de la legislación social ${ }^{147}$. Claridad informaba, el día de la sublevación militar, que «la huelga de Quirós» seguía en «punto muerto»148.

El 3 de junio de 1936 paraba todo el ramo de la sastrería de Madrid, en solidaridad con los del taller Chapette, cuyo conflicto se había desencadenado tres meses atrás en protesta por las represalias patronales y el lock-out, practicado con estas palabras: « ¡Habéis votado al Frente Popular, pues que os dé de comer el Frente Popular!» ${ }^{149}$. La intervención del Sindicato de Obreros y Obreras de la Aguja de Madrid (UGT), puso término al conflicto mantenido desde hacía un mes por las guanteras de la Casa Aguilar (calle Atocha, 63), propiedad de Florentino Martínez, en demanda de aumento de jornales y supresión del trabajo a destajo.

140 Mundo Obrero, 14/1/1936, p. 4.

141 Mundo Obrero, 11/3/1936, p. 1.

142 Mundo Obrero, 17/3/1936, p. 4; El Socialista, 18/3/1936.

143 Solidaridad Obrera, $1 / 5 / 1936$.

144 Mundo Obrero, 30/3/1936.

145 El Socialista, 16/5/1936.

146 Mundo Obrero, 29/5/1936, p. 2; El Socialista, 9/7/1936, p. 4.

147 El Socialista, 2/7/1936, p. 4.

148 Claridad, 18/7/1936, p. 4.

149 El Socialista, 4/6/1936, p. 5. 
En julio de 1936, se declararon en huelga las lavanderas de la calle Juan de Olías, en Tetuán de las Victorias, exigiendo la readmisión de una compañera despedida. El 16 de julio de 1936, después de una lucha de dieciséis días, los obreras de las fábrica 'Gal y Floria'obtuvieron satisfacción a sus demandas ${ }^{150}$. En julio de 1936, se declararon también en huelga las sirvientas de un pequeño pueblo sevillano, Visor de Alcor ${ }^{151}$.

\section{Conclusiones}

El nuevo contexto no implicó alteraciones significativas en la condición social de la mujer. Las consignas propagadas por los partidos y sindicatos obreros no se orientaron en ese sentido, sino que se arengó a la compañera a intervenir en las luchas sociales para conseguir la instauración de un nuevo orden social, un orden ideal donde el rol de las mujeres a veces incluía sin rebozo, incluso con carácter prioritario, la ineludible dedicación femenina a los hijos y al hogar. Sin embargo, el feminismo avanzaba aunque fuera de manera difusa: el sábado 18 de julio de 1936 fue desconvocada una conferencia en la Casa del Pueblo de la calle Piamonte (Madrid) sobre derechos de las mujeres. La conferenciante era Isabel de Palencia.

La participación de la mujer en el movimiento obrero y su contribución a la protesta social es bastante mayor de lo que normalmente es admitido, incluso en la propia historiografía del movimiento obrero en España. Los estudios en torno a la mujer en el obrerismo español sólo han empezado a rehabilitar las figuras de las activistas y a cuestionar las tesis de la historiografía anterior en torno a la ausencia de mujeres en el conflicto social. Un ejemplo de esto, es el alto nivel de participación electoral femenina en la victoria del Frente Popular y su contribución a la protesta social en la primavera del 36. El artículo, por tanto, contribuye desde esta nueva perspectiva, y desde la utilización de nuevas fuentes, a ampliar y profundizar las líneas de investigación existentes sobre el movimiento obrero femenino (circunscrito al ámbito geográfico español y frentepopulista) y su contribución al esfuerzo republicano, contribuyendo de esta manera a dignificar y a engrandecer la contribución de la misma al movimiento social y revolucionario.

150 El Socialista, $17 / 7 / 1936$, p. 4.

151 Mundo Obrero, 8/7/1936, p. 3. 
